\title{
Effects of Different 3-Year Cropping Systems on Soil Microbial Communities and Rhizoctonia Diseases of Potato
}

\author{
Robert P. Larkin and C. Wayne Honeycutt
}

U.S. Department of Agriculture-Agricultural Research Service, New England Plant, Soil, and Water Laboratory, Orono, ME 04469. Accepted for publication 6 September 2005.

\begin{abstract}
Larkin, R. P., and Honeycutt, C. W. 2006. Effects of different 3-year cropping systems on soil microbial communities and Rhizoctonia diseases of potato. Phytopathology 96:68-79.

Eight different 3-year cropping systems, consisting of soybean-canola, soybean-barley, sweet corn-canola, sweet corn-soybean, green bean-sweet corn, canola-sweet corn, barley-clover, and continuous potato (nonrotation control) followed by potato as the third crop in all systems, were established in replicated field plots with two rotation entry points in Presque Isle, ME, in 1998. Cropping system effects on soil microbial community characteristics based on culturable soil microbial populations, single carbon source substrate utilization (SU) profiles, and whole-soil fatty acid methyl ester (FAME) profiles were evaluated in association with the development of soilborne diseases of potato in the 2000 and 2001 field seasons. Soil populations of culturable bacteria and overall microbial activity were highest following barley, canola, and sweet corn crops, and lowest following continuous potato. The SU profiles derived from BIOLOG ECO plates indicated higher substrate richness and diversity and greater utilization of certain carbohydrates, carboxylic acids, and amino acids associated with barley, canola, and some sweet corn rotations, indicating distinct differences in functional attributes of microbial communities among cropping systems. Soil FAME profiles also demonstrated distinct differences among cropping systems in their relative com-
\end{abstract}

ABSTRACT position of fatty acid types and classes, representing structural attributes of microbial communities. Fatty acids most responsible for differentiation among cropping systems included 12:0, 16:1 $\omega 5 \mathrm{c}, 16: 1 \omega 7 \mathrm{c}, 18: 1 \omega 9 \mathrm{c}$, and 18:2 $\omega 6 \mathrm{c}$. Based on FAME biomarkers, barley rotations resulted in higher fungi-to-bacteria ratios, sweet corn resulted in greater mycorrhizae populations, and continuous potato produced the lowest amounts of these and other biomarker traits. Incidence and severity of stem and stolon canker and black scurf of potato, caused by Rhizoctonia solani, were reduced for most rotations relative to the continuous potato control. Potato crops following canola, barley, or sweet corn provided the lowest levels of Rhizoctonia disease and best tuber quality, whereas potato crops following clover or soybean resulted in disease problems in some years. Both rotation crop and cropping sequence were important in shaping the microbial characteristics, soilborne disease, and tuber qualities. Several microbial parameters, including microbial populations and SU and FAME profile characteristics, were correlated with potato disease or yield measurements in one or both harvest years. In this study, we have demonstrated distinctive effects of specific rotation crops and cropping sequences on microbial communities and have begun to relate the implications of these changes to crop health and productivity.

Additional keywords: microbial community structure, soil microbiology, Solanum tuberosum.
Commercial production of potato (Solanum tuberosum L.) in the northeast has declined by over 100,000 acres over the past 30 years due to numerous financial and production constraints, including lack of profitable rotation crops, high plant disease pressure, high fertilizer requirements, and stagnant or declining yield levels. Current production practices are based on a 2-year (or shorter) rotation with a low-maintenance grain forage crop (such as barley or oat). Although 2-year rotations have been shown to reduce disease levels compared with continuous potato $(22,40$, 44 ), longer rotation lengths of 3 or 4 years between potato crops are known to be more effective in controlling soilborne diseases $(8,21,36,40)$. Soilborne potato diseases of most concern in the northeast include Rhizoctonia diseases (stem and stolon canker and black scurf of tubers), common scab, powdery scab, and white mold, caused by Rhizoctonia solani, Streptomyces scabiei, Spongospora subterranea, and Sclerotinia sclerotiorum, respectively.

Although many studies have been conducted over the years assessing specific rotation effects on potato diseases and yield, little is known about the nature and mechanisms involved with those

Corresponding author: R. P. Larkin; E-mail address: larkin@maine.edu

DOI: 10.1094/PHYTO-96-0068

This article is in the public domain and not copyrightable. It may be freely reprinted with customary crediting of the source. The American Phytopathological Society, 2006. effects. In most cases, it is not known what specific changes are occurring in the soil which lead to reductions in pathogens and diseases. Generally, rotation crops can reduce soilborne pathogens by any (or all) of three different mechanisms: (i) by serving to interrupt or break the host-pathogen cycle of inoculum production, growth, or survival; (ii) by altering the soil physical, chemical, or biological characteristics and stimulating microbial activity, diversity, or plant-beneficial microbes, making the soil environment less conducive for pathogen development or survival; and (iii) by direct inhibition of pathogens, either through production of inhibitory or toxic compounds in the roots or plant residues, or by stimulating specific microbial antagonists which directly suppress pathogen inoculum.

One of the most important effects rotation crops have on the soil environment is on soil microbial communities $(2,10,33)$. However, relatively little is known about the precise nature of these changes and their consequences. Several studies have determined significant differences among microbial communities from different long-term cropping and management regimes $(4,12,47$, 48), and many have examined rhizosphere effects of different plant species $(19,23,24,30-32,39)$. However, few studies have documented the specific effects of different rotation crops on soil microbial communities within a defined crop production system $(25,29)$, or have tried to relate these differences with effects on soilborne disease. Nevertheless, a better understanding of the relationships among specific cropping systems and other crop management practices, the resultant changes in soil microbial ecology, 
and their roles and effects on crop health and productivity is necessary for the development of more efficient, sustainable crop production systems.

Community-level soil microbial assays based on phospholipid fatty acid (PLFA) $(3,4,15,47,48)$ and fatty acid methyl ester (FAME) $(9,23,25)$ profiling, as well as sole carbon source substrate utilization (SU) $(16,19,46)$ profiling, have been used to detect and characterize differences in soil microbial communities caused by varying soils and land use $(23,45)$, agricultural management practices $(4,14,29,41)$, and plant species present $(13,32$, 39 ), among other factors. Although no one approach provides a complete depiction of soil microbial characteristics, each of these approaches provides a slightly different perspective. The use of multiple approaches can provide a more complete representation of soil microbial characteristics. In our previous research (25), we combined the use of FAME and SU profiling techniques with culture-based microorganism population data to characterize soil microbial communities associated with various 2 -year crop rotations within potato cropping systems in Maine. In that research, we observed distinctive changes in soil microbial community characteristics directly related to the various rotation crops grown. In the present study, we used these same microbial assessment approaches to evaluate the influence of specific 3-year cropping systems on soil microbial community characteristics and soilborne potato diseases. The specific objectives of this research were to (i) assess whether rotation crop effects on soil microbial community characteristics would be similar to or different from those previously observed (25) when studies were conducted in a different soil, at a different site, and under different environmental conditions; (ii) evaluate effects of rotation crop sequences (different combinations of rotation crops) in 3-year rotations on soil microbial communities; (iii) evaluate effects of the different rotations on development of soilborne diseases and tuber yield; and (iv) begin to relate the observed changes in microbial characteristics to disease and yield parameters.

\section{MATERIALS AND METHODS}

Field sites and soil sampling. Research plots were established at a field site in Presque Isle, ME in 1998 for the purpose of developing a long-term site for study of specific 3-year cropping systems for potato production. Soil type at the site is a Caribou sandy loam, a fine-loamy, mixed, frigid, Typic Haplorthod. This site was unmanaged grassland for the last few years prior to establishing our study plots, but potato had been grown here in previous years. Crops used in rotation with potato included barley (Hordeum vulgare L.) underseeded with red clover (Trifolium pratense L.), canola (Brassica napus L.), green bean (Phaseolus vulgaris L.), soybean (Glycine $\max$ (L.) Merr.), and sweet corn (Zea mays L.) in various combinations and sequences, in addition to a continuous potato (nonrotation) control. These rotation crops were chosen for study based primarily on their compatibility with northeastern climate and production practices, their perceived potential for profitable production, and their potential positive effects on soil properties, but not necessarily on their potential for effects on soil microbial communities or reduction of soilborne diseases. Eight different cropping systems were established, consisting of two different crops as crop 1 and 2 (except for the continuous potato control) followed by potato as the third crop (Table 1). Field plots were arranged in a randomized complete block design consisting of four replicate plots $(30.5$ by $3.7 \mathrm{~m}$ ) for each of the eight cropping systems at two different rotation entry points $(4 \times$ $8 \times 2=64$ plots total). Thus, each block consisted of two separate cropping cycles for each rotation (with potato planted in the first and third year, respectively). In 1998, one set of plots (cycle A) was planted to rotation crop 1; whereas, in the other plots (cycle B), all plots were planted to potato. In 2000, for example, for cycle A, all plots were planted to potato (year 3 of rotation) and, in cycle B, all plots were planted to rotation crop 2. Thus, the effects of two separate 3-year rotation cycles could be assessed on potato crops in consecutive years (2000 and 2001). Tillage for all plots consisted of primary tillage with a chisel plow and then secondary tillage of one to two diskings prior to planting. Cut seed pieces of potato cv. Russet Burbank were planted by hand in each potato plot (four rows, $0.9-\mathrm{m}$ centers, with a $35-\mathrm{cm}$ spacing between plants) in May of each year. Potato plots were fertilized with the equivalent of $\mathrm{N}$ at $224 \mathrm{~kg} \mathrm{ha}^{-1}$ and $\mathrm{P}_{2} \mathrm{O}_{5}$ and $\mathrm{K}_{2} \mathrm{O}$ at $249 \mathrm{~kg} \mathrm{ha}^{-1}$. Potato plots also were sprayed regularly throughout the growing season with alternating applications of mancozeb and chlorothalonil at recommended rates for the control of late blight. All other crops were managed using recommended production practices, including fertilizer rates, pesticide applications, and weed control measures for that particular crop. Data presented in this article were collected for the 2000, 2001, and spring 2002 growing seasons, which represented the third, fourth, and fifth year of these rotations. Potato crops were evaluated in 2000 and 2001.

Soil samples were collected from each plot twice during the growing season, in the spring (preplant) and in the fall (postharvest). Soil samples consisted of 10 soil cores ( 15 by $2 \mathrm{~cm}$ in diameter) taken from the middle two rows and between row area (for crops with closer spacing and many rows, the middle 2-m section). All 10 cores were combined to make one composite soil sample per plot at each sampling date. Upon return from the field, soil samples were passed through a $3.35-\mathrm{mm}$ sieve to remove rocks and large organic debris. Samples were stored in plastic bags at $10^{\circ} \mathrm{C}$ and processed as soon as possible, usually within 1 week and not longer than 1 month after sampling. For most assays, three subsamples were processed from each composite plot sample.

Microbial populations and activity. General microbial populations were determined by soil dilution plating on various agar media. For each of three subsamples from each composite soil sample, $10 \mathrm{~g}$ of soil was weighed, added to $90 \mathrm{ml}$ of sterile $0.2 \%$ water agar, vigorously stirred for $5 \mathrm{~min}$, serially diluted and plated on: $10 \%$ tryptic soy agar (TSA) for total bacterial counts; potato dextrose agar (PDA) with $50 \mathrm{mg}$ of chlortetracycline and tergitol at $1 \mathrm{ml} \mathrm{liter}^{-1}$ added for total fungal counts (28); selective King's medium B (KMB) amended with $75 \mathrm{mg}$ of penicillin, $45 \mathrm{mg}$ of novabiocin, and $75 \mathrm{mg}$ of cyclohexamide per liter (37) for overall Pseudomonas spp. and fluorescent pseudomonad counts; and water agar amended with $50 \mathrm{mg}$ of nystatin, $5 \mathrm{mg}$ of polymixin $\mathrm{B}, 1 \mathrm{mg}$ of penicillin, and $50 \mathrm{mg}$ of cyclohexamide per

TABLE 1. List of the rotation crops, sequences, and abbreviations used to designate the different 3-year cropping systems established in research field plots in Presque Isle, $\mathrm{ME}^{\mathrm{y}}$

\begin{tabular}{llll}
\hline Abbreviation & \multicolumn{1}{c}{ Crop 1 } & Crop 2 & Crop 3 \\
\hline $\mathrm{B}-\mathrm{Cl}$ & Barley/clover & Clover & Potato \\
$\mathrm{Sc}-\mathrm{C}$ & Sweet corn & Canola & Potato \\
$\mathrm{C}-\mathrm{Sc}$ & Canola & Sweet corn & Potato \\
$\mathrm{Sc}-\mathrm{Sb}$ & Sweet corn & Soybean & Potato \\
$\mathrm{Sb}-\mathrm{C}$ & Soybean & Canola & Potato \\
$\mathrm{Sb}-\mathrm{B}$ & Soybean & Barley/clover & Potato \\
$\mathrm{Gb}-\mathrm{Sc}$ & Green bean & Sweet corn & Potato \\
$\mathrm{P}-\mathrm{P}$ & Potato & Potato & Potato
\end{tabular}

y Field plots were established in 1998 in a randomized complete block design with two plots for each cropping system per block (representing different rotation entry points; crop 1 and crop 3 planted in first year) and four replicate blocks. Each plot was 30.5 by $3.7 \mathrm{~m}$ (eight rotations $\times$ two entry points $\times$ four blocks $=64$ plots).

${ }^{z}$ Barley/clover represents the barley crop underseeded at planting with red clover as a cover crop. The second-year clover crop represents allowing the underseeded clover to overwinter and continue growing through the following year, with no additional tillage or seeding. A 2-year barley/clover-potato rotation represents the current industry standard rotation crop for potato production in the northeast. 
liter (11) for actinomycete counts. Bacterial and actinomycete plates were incubated at $28^{\circ} \mathrm{C}$ for 3 and 10 days, respectively, and fungal plates at $25^{\circ} \mathrm{C}$ for 7 days prior to enumeration of viable colonies. The KMB plates were examined under a long-wave UV light for detection of the fluorescent pigment characteristic of fluorescent pseudomonads. Colonies of Trichoderma spp. and a particular Penicillium sp. were identified on fungal plates by their distinctive colony morphology and enumerated separately.

SU profiles. The capability of soil microbial communities to utilize a variety of sole carbon sources was assessed using BIOLOG ECO plates (BIOLOG Inc., Hayward, CA) by a procedure adapted from Garland and Mills (16) as described by Larkin (25). Each plate contained three replicate sets of 31 different sole carbon sources, including carbohydrates, carboxylic acids, amino acids, amides, polymers, and miscellaneous compounds, as well as controls (blank wells) in a 96-well microplate. The rate of utilization of the carbon sources was indicated by the reduction of tetrazolium, a redox indicator dye, which changes from colorless to purple. One ECO plate was prepared for each of two soil subsamples (10 $\mathrm{g}$ of soil serially diluted as described for microbial plate counts), with 150- $\mu$ l aliquots of a final dilution of 1:5,000 added to each of the 96 wells/plate. The plates were incubated at $22^{\circ} \mathrm{C}$ and optical density was determined on a plate reader at 590 and $760 \mathrm{~nm}$ after 48, 72, and $96 \mathrm{~h}$ of incubation. Optical density readings were corrected for the control (blank) wells on each
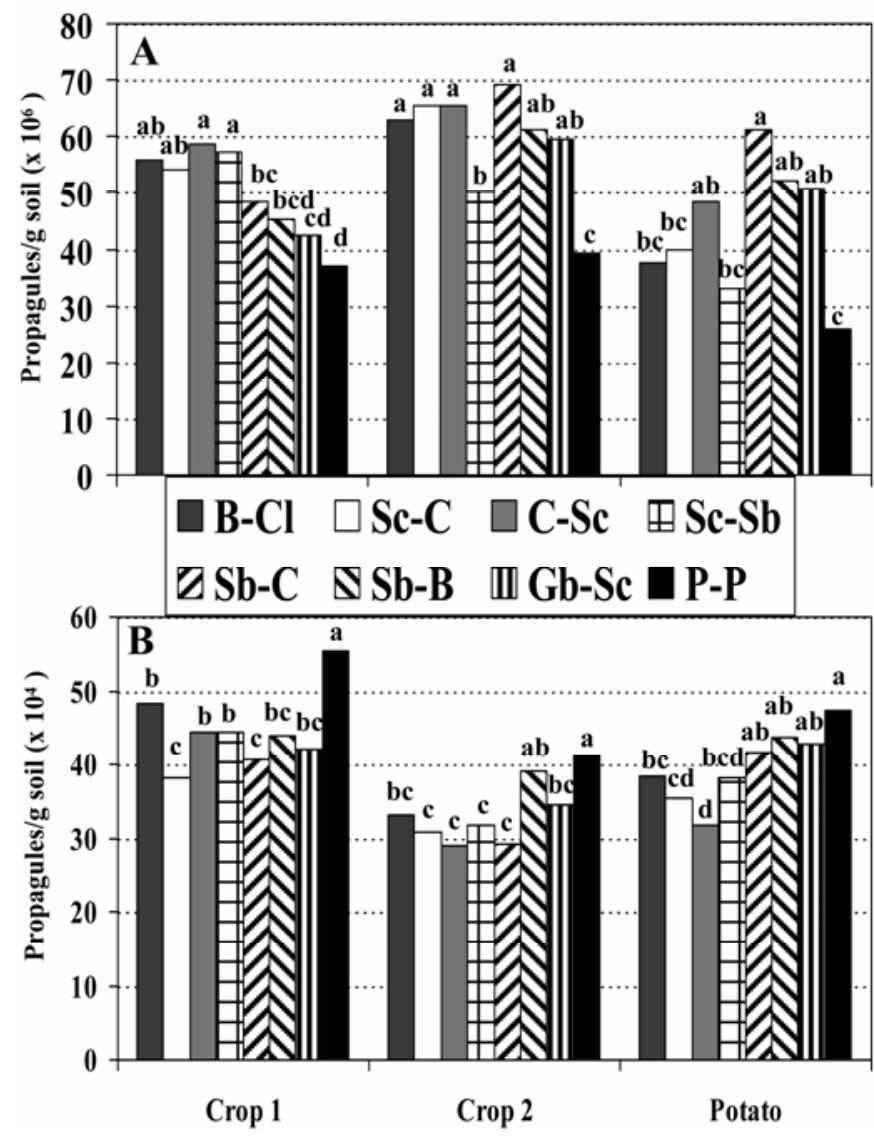

Fig. 1. General soil microbial populations of culturable $\mathbf{A}$, bacteria and $\mathbf{B}$, fungi following each cropping stage of different 3-year cropping systems. Cropping systems (crop 1-crop 2) consisted of $\mathrm{B}-\mathrm{Cl}=$ barley/cloverclover, $\mathrm{Sc}-\mathrm{C}=$ sweet corn-canola, $\mathrm{C}-\mathrm{Sc}=$ canola-sweet corn, $\mathrm{Sc}-\mathrm{Sb}=$ sweet corn-soybean, $\mathrm{Sb}-\mathrm{C}=$ soybean-canola, $\mathrm{Sb}-\mathrm{B}=$ soybean-barley/clover, $\mathrm{Gb}-\mathrm{Sc}=$ green bean-sweet corn, and $\mathrm{P}-\mathrm{P}=$ consecutive potato (control). All systems included potato as the third crop. For each cropping stage, bars with the same letter are not significantly different according to Fisher's protected least significant difference at $P=0.05$. Values represent combined data from spring soil samples collected from each of two field seasons for each cropping stage. plate before data analyses. In addition to analyses comparing individual substrates, SU data also were analyzed for substrate richness (the number of substrates utilized), substrate evenness (the distribution of color development among the substrates), and substrate diversity (as Shannon's diversity index) (46). Average well color development (AWCD), calculated as the average optical density across all wells per plate, was used as an indicator of general microbial activity (25).

FAME profiles. Soil community fatty acid profiles were constructed from whole-soil extractions of FAMEs according to a modification of the Microbial Identification System (MIS; MIDI, Inc., Newark, DE) standard protocol as described by Larkin (25). Extractions were conducted on each of three 4-g soil subsamples per plot. Each sample was saponified, mixed, heated, methylated, mixed, cooled, extracted, and washed as described previously (25). The organic phase then was transferred to a vial for subsequent analysis with gas chromatography using an automated procedure developed by MIDI, Inc., which utilizes an HP 6890 gas chromatograph (Hewlett-Packard, Wilmington, DE) with an HP Ultra-2 capillary column and flame ionization detector. The fatty acids were identified according to the Eukary method and naming table software developed for the MIS. The fatty acid nomenclature used is as follows: total number of carbon atoms : number of double bonds, followed by the position of the double bond from the methyl end of the molecule. cis and trans geometry are indicated by the suffixes c and t. Anteiso- and iso-branching are indicated by the suffixes ant and iso. Fatty acids also were analyzed by structural classes, including saturated straight chain, monounsaturated, polyunsaturated, branched, and hydroxy fatty acid classes. These classes and select individual fatty acids were used as indicators (biomarkers) for particular microorganism groups $(3,6,25,47)$. Only fatty acids which accounted for at least $0.25 \%$ of the total fatty acid content over all observations from any given sampling date were included in the analyses. This prevented fatty acids that were only sporadically detected or unreliably quantified from influencing the analyses (3). In addition, dicarboxylic acids and fatty acids with a chain length of $>20$ carbons were not included in the analyses because these generally are not of microbial origin (48). With these criteria, analyses consisted of 40 to 45 unique fatty acids.

Soilborne potato disease and tuber yield. In both years that all plots within the cropping cycles were planted to potato (2000 and 2001 for cycles A and B, respectively), potato plants were monitored in the field for signs and symptoms of soilborne diseases, including stem and stolon canker, white mold, and Verticillium wilt. In August 2001 only, four potato hills per plot, each containing multiple potato stems per plant, were destructively sampled (hand dug) to more accurately assess stem and stolon canker incidence and severity. Severity was determined on each stem or stolon using a 0 -to-5 rating scale, where $0=$ no symptoms; 1 = discoloration, slight lesion; 2 = substantial lesion and necrosis covering $<50 \%$ of stem or stolon diameter; $3=$ lesion covering $>50 \%$ stem or stolon diameter; $4=$ large lesion girdling stem $(100 \%)$; and $5=$ stem (or stolon) girdled, plant (or stolon) dead. In October of both years, potato tubers were harvested by hand from a $12.2-\mathrm{m}$ row section of a middle row from each plot. Tubers were washed, graded, and rated for incidence and severity of several soilborne diseases of tubers, including black scurf, common scab, and powdery scab. Disease severity was determined as the approximate percent surface coverage of the visible symptoms. Yield was evaluated as the total weight of tubers per $12.2 \mathrm{-m}$ row, and marketable weight as the total weight of tubers $>114 \mathrm{~g}$ each. The percentage of tubers with obvious deformities or misshapenness was determined from the weight of misshapen tubers relative to the total weight of all tubers harvested.

Data analyses. Microbial population counts and most other data were analyzed using standard analysis of variance (ANOVA) 
with factorial treatment structure and interactions. The SU and FAME data were analyzed by principal components analysis (PCA) using the covariance matrix followed by multivariate ANOVA. The covariance matrix provides a more straightforward interpretation of principal components (PCs), does not sacrifice information for scale-invariance as does the correlation matrix, and is appropriate for these types of data (17). The SU data also were analyzed by analysis of covariance and adjusted least significant means compared among rotations for substrate richness, evenness, and diversity analyses. To account for the influence of AWCD on SU patterns, AWCD was used as a covariate in these analyses $(13,20)$. Because each of the two cropping cycles within each cropping system represented a different crop each year, data for each cropping cycle were analyzed separately (as cycle A and cycle B) for evaluating crop effects among cropping systems. For most analyses, the spring sampling data, representing the effects of the crop from the previous season, were used to evaluate and differentiate cropping systems and their different crop sequences. Data from each season and cropping cycle were analyzed separately. Data from multiple seasons also were combined and analyzed (with year as an additional factor) to indicate overall effects of the cropping systems. Correlation analyses were conducted (using Pearson's product-moment correlation coefficients) to relate the various microbial parameters with each other and to the observed potato disease and yield data in the field. Analyses were conducted on various microbial parameters collected in spring 2000 and 2001 and correlated with potato production data from their respective potato growing seasons, both separately and combined over both years. Significance was evaluated at $P<0.05$ for all tests. Mean separation was accomplished with Fisher's protected least significant difference test. All analyses were conducted using the Statistical Analysis Systems (version 7; SAS Institute, Cary, NC). Most assays consisted of three subsamples and four replications (blocks). All SU data presented are based on 72-h incubation readings.

\section{RESULTS}

Microbial populations. Cropping system had significant effects on microbial populations at each sampling date. Although microbial populations and the influence of the cropping systems varied somewhat from year to year, average spring populations over two field seasons summarized the overall effects of the cropping systems on soil microbial populations (Fig. 1). In the spring following planting of rotation crop 1, total soil populations of culturable bacteria tended to be highest following canola, barley, and sweet corn, and lowest following green bean and potato crops (Fig. 1A). After rotation crop 2, bacterial populations were higher in all rotations than continuous potato and also higher in the barley-clover (B-Cl), sweet corn-canola (Sc-C), canolasweet corn $(\mathrm{C}-\mathrm{Sc})$, and soybean-canola $(\mathrm{Sb}-\mathrm{C})$ rotations than in the sweet corn-soybean $(\mathrm{Sc}-\mathrm{Sb})$ rotation. After all plots were planted to potato (crop 3), the $\mathrm{Sb}-\mathrm{C}, \mathrm{Sb}-\mathrm{B}, \mathrm{Gb}-\mathrm{Sc}$, and $\mathrm{C}-\mathrm{Sc}$ rotations maintained higher bacterial populations than the continuous potato controls (Fig. 1A). Overall fungal populations, however, tended to be higher in continuous potato at all cropping stages and somewhat lower following certain canola and sweet corn rotations (Fig. 1B).

Further analyses of selected subgroups of bacterial and fungal populations revealed additional trends among the different cropping systems (Table 2). Populations of Pseudomonas spp. tended to be highest in the $\mathrm{Sb}-\mathrm{C}, \mathrm{B}-\mathrm{Cl}$, and $\mathrm{Sc}-\mathrm{C}$ systems after rotation crop 2, and the $\mathrm{C}-\mathrm{Sc}, \mathrm{Sc}-\mathrm{C}$, and $\mathrm{Sb}-\mathrm{C}$ systems after potato, and were consistently lower in potato-potato (P-P) than most other rotations throughout all stages of the cropping cycle. Following rotation crops 1 and 2, populations of actinomycetes varied among the

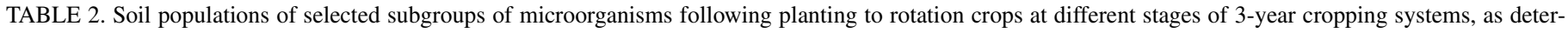
mined by soil dilution plating on selective media

\begin{tabular}{|c|c|c|c|c|}
\hline \multirow[b]{2}{*}{ Cropping stage/rotation ${ }^{\mathrm{y}}$} & \multicolumn{4}{|c|}{ Microorganism group (CFU/g of soil $)^{\mathrm{z}}$} \\
\hline & Actinomycetes $\left(\times 10^{6}\right)$ & Pseudomonas $\left(\times 10^{4}\right)$ & Trichoderma $\left(\times 10^{4}\right)$ & Penicillium $\left(\times 10^{4}\right)$ \\
\hline \multicolumn{5}{|l|}{ Following crop 1} \\
\hline $\mathrm{B}-\mathrm{Cl}$ & $17.3 \mathrm{a}$ & $55.6 \mathrm{a}$ & $2.0 \mathrm{bc}$ & $6.5 \mathrm{bcd}$ \\
\hline Sc-C & $15.2 \mathrm{ab}$ & $59.2 \mathrm{a}$ & $2.2 \mathrm{bc}$ & $4.6 \mathrm{de}$ \\
\hline $\mathrm{C}-\mathrm{Sc}$ & $14.1 \mathrm{ab}$ & $51.8 \mathrm{a}$ & $3.6 \mathrm{a}$ & 5.1 cde \\
\hline $\mathrm{Sc}-\mathrm{Sb}$ & $12.9 \mathrm{~b}$ & $61.3 \mathrm{a}$ & $2.9 \mathrm{ab}$ & $3.9 \mathrm{e}$ \\
\hline $\mathrm{Sb}-\mathrm{C}$ & $14.4 \mathrm{ab}$ & $45.0 \mathrm{ab}$ & $2.3 \mathrm{bc}$ & $7.2 \mathrm{bc}$ \\
\hline $\mathrm{Sb}-\mathrm{B}$ & $12.9 \mathrm{~b}$ & $54.0 \mathrm{a}$ & $1.3 \mathrm{c}$ & $7.6 \mathrm{~b}$ \\
\hline $\mathrm{Gb}-\mathrm{Sc}$ & $14.8 \mathrm{ab}$ & $24.3 \mathrm{bc}$ & $2.1 \mathrm{bc}$ & $6.3 \mathrm{bcd}$ \\
\hline P-P & $14.6 \mathrm{ab}$ & $17.7 \mathrm{c}$ & $1.2 \mathrm{c}$ & $12.8 \mathrm{a}$ \\
\hline \multicolumn{5}{|l|}{ Following crop 2} \\
\hline $\mathrm{B}-\mathrm{Cl}$ & $10.9 \mathrm{~b}$ & $124.6 \mathrm{a}$ & $0.9 \mathrm{c}$ & $5.9 \mathrm{bc}$ \\
\hline Sc-C & $13.0 \mathrm{ab}$ & $111.9 \mathrm{ab}$ & $2.6 \mathrm{a}$ & $4.2 \mathrm{bc}$ \\
\hline $\mathrm{C}-\mathrm{Sc}$ & $14.5 \mathrm{a}$ & $73.4 \mathrm{c}$ & $2.2 \mathrm{ab}$ & $3.9 \mathrm{c}$ \\
\hline $\mathrm{Sc}-\mathrm{Sb}$ & $14.8 \mathrm{a}$ & 88.2 bc & $2.3 \mathrm{a}$ & $4.2 \mathrm{bc}$ \\
\hline $\mathrm{Sb}-\mathrm{C}$ & $14.7 \mathrm{a}$ & $134.9 \mathrm{a}$ & $1.8 \mathrm{ab}$ & $4.1 \mathrm{bc}$ \\
\hline $\mathrm{Sb}-\mathrm{B}$ & $11.2 \mathrm{~b}$ & $75.0 \mathrm{c}$ & $1.4 \mathrm{bc}$ & $6.6 \mathrm{~b}$ \\
\hline $\mathrm{Gb}-\mathrm{Sc}$ & $11.9 \mathrm{~b}$ & $75.4 \mathrm{c}$ & $1.2 \mathrm{c}$ & $5.3 \mathrm{bc}$ \\
\hline P-P & $12.2 \mathrm{ab}$ & $18.4 \mathrm{~d}$ & $1.2 \mathrm{c}$ & $10.1 \mathrm{a}$ \\
\hline \multicolumn{5}{|l|}{ Following potato } \\
\hline $\mathrm{B}-\mathrm{Cl}$ & $10.9 \mathrm{bc}$ & $62.9 \mathrm{~b}$ & $1.5 \mathrm{bc}$ & $7.5 \mathrm{~b}$ \\
\hline $\mathrm{Sc}-\mathrm{C}$ & $10.6 \mathrm{bc}$ & $107.3 \mathrm{a}$ & $3.2 \mathrm{a}$ & $6.2 \mathrm{bc}$ \\
\hline $\mathrm{C}-\mathrm{Sc}$ & $13.3 \mathrm{bc}$ & $124.3 \mathrm{a}$ & $3.5 \mathrm{a}$ & $4.9 \mathrm{c}$ \\
\hline $\mathrm{Sc}-\mathrm{Sb}$ & $8.7 \mathrm{c}$ & $37.3 \mathrm{bc}$ & $2.6 \mathrm{ab}$ & $4.6 \mathrm{c}$ \\
\hline $\mathrm{Sb}-\mathrm{C}$ & $18.2 \mathrm{a}$ & $112.1 \mathrm{a}$ & $1.6 \mathrm{bc}$ & $6.7 \mathrm{bc}$ \\
\hline $\mathrm{Sb}-\mathrm{B}$ & $14.3 \mathrm{ab}$ & $61.5 \mathrm{~b}$ & $1.3 \mathrm{c}$ & $7.8 \mathrm{~b}$ \\
\hline $\mathrm{Gb}-\mathrm{Sc}$ & $11.1 \mathrm{bc}$ & $43.9 \mathrm{bc}$ & $2.8 \mathrm{a}$ & $6.0 \mathrm{bc}$ \\
\hline P-P & $8.9 \mathrm{c}$ & $19.8 \mathrm{c}$ & $0.7 \mathrm{c}$ & $11.9 \mathrm{a}$ \\
\hline
\end{tabular}

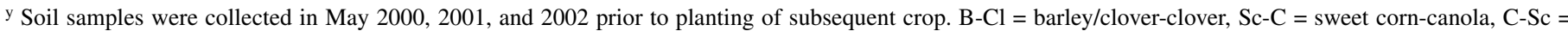
canola-sweet corn, $\mathrm{Sc}-\mathrm{Sb}=$ sweet corn-soybean, $\mathrm{Sb}-\mathrm{C}=$ soybean-canola, Sb-B $=$ soybean-barley/clover, Gb-Sc $=$ green bean-sweet corn, and $\mathrm{P}-\mathrm{P}=\mathrm{consecutive}$ potato (control)

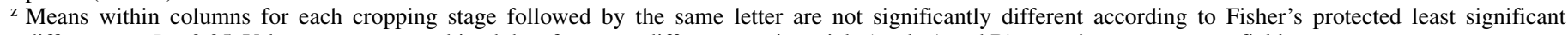
difference at $P=0.05$. Values represent combined data from two different rotation trials (cycle A and B), meaning two separate field seasons. 
cropping systems, but no consistent trends were associated with specific crops. After the potato crop, actinomycete populations were highest in the Sb-C system and lowest in the Sc-Sb and P-P systems. Populations of certain fungal groups also had some consistent differences among the rotations, with populations of Trichoderma spp. tending to be lower in P-P and slightly higher in C-Sc and $\mathrm{Sc}-\mathrm{C}$ rotations than in many other rotations at all stages of the cropping cycle. Populations of a particular Penicillium sp. (species as yet unidentified) were substantially higher in continuous potato than all other rotations at all stages of the rotation cycle. Populations of this single species of Penicillium was closely associated with potato and potato roots. The high populations of this single organism accounted for most of the increased total fungal counts observed on soil dilution plates from the P-P rotation.
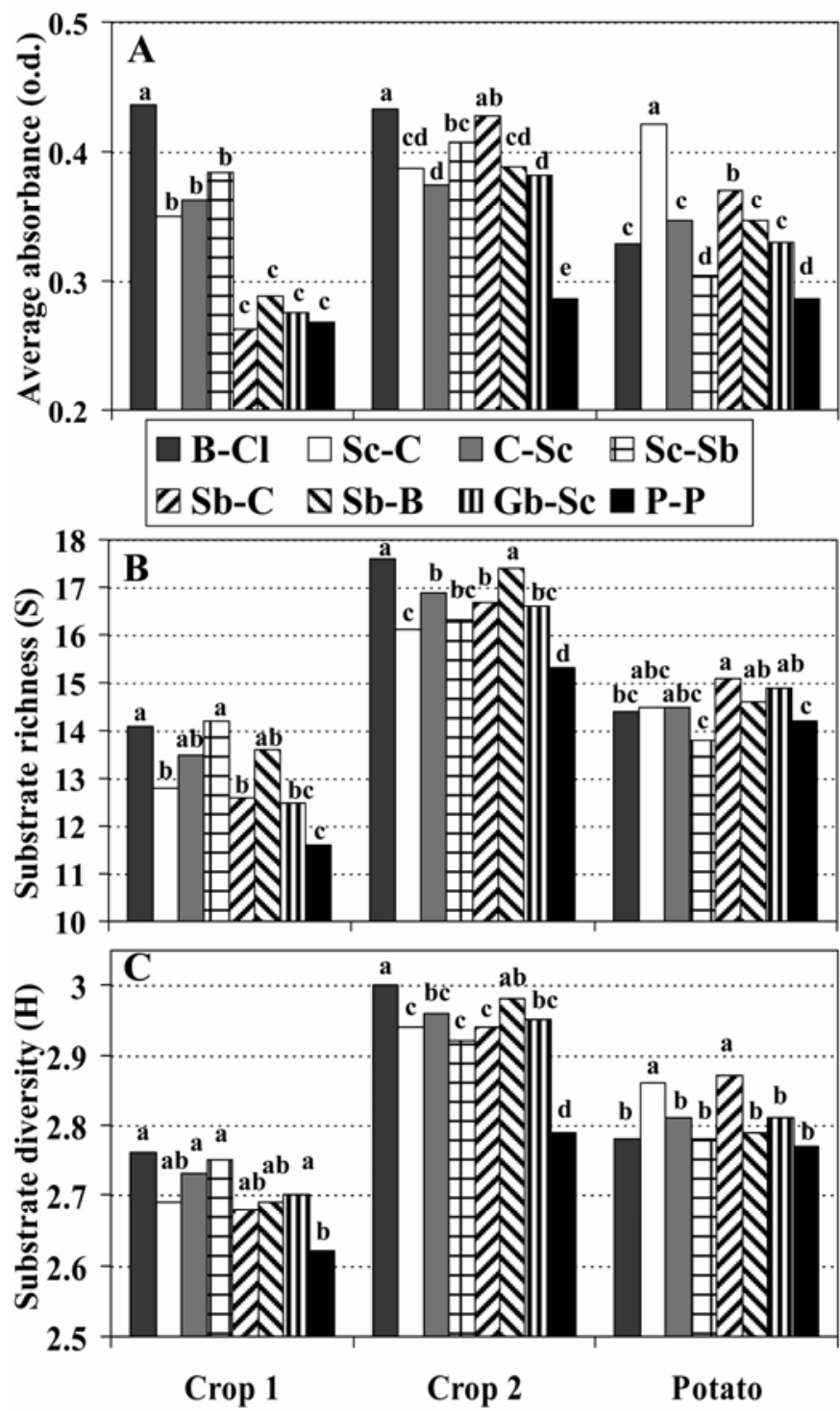

Fig. 2. Substrate utilization characteristics of soil microbial communities following each cropping stage of different 3-year cropping systems, including A, general microbial activity (AWCD), B, substrate richness (number of substrates effectively utilized, and C, substrate diversity (Shannon's diversity index) as determined using Biolog ECO plates. Cropping systems (crop 1 and crop 2) consisted of $\mathrm{B}-\mathrm{Cl}=$ barley/clover-clover, $\mathrm{Sc}-\mathrm{C}=$ sweet corn-canola, $\mathrm{C}$ $\mathrm{Sc}=$ canola-sweet corn, $\mathrm{Sc}-\mathrm{Sb}=$ sweet corn-soybean, $\mathrm{Sb}-\mathrm{C}=$ soybean-canola, $\mathrm{Sb}-\mathrm{B}=$ soybean-barley/clover, $\mathrm{Gb}-\mathrm{Sc}=$ green bean-sweet corn, and $\mathrm{P}-\mathrm{P}=\mathrm{con}-$ secutive potato (control). All systems included potato as the third crop. For each cropping stage, bars with the same letter are not significantly different according to Fisher's protected least significant difference at $P=0.05$. Values represent combined data from spring soil samples collected from each of two field seasons for each cropping stage.
SU profiles. Cropping system significantly affected overall SU, richness, and diversity in all stages of the cropping cycle. Overall SU was determined by AWCD of all substrates and is an indicator of general microbial activity. After crop 1, B-Cl plots had the highest overall activity, whereas plots following soybean, green bean, and potato plantings had lower activity than all other rotations (Fig. 2A). After crop 2, the $\mathrm{B}-\mathrm{Cl}$ and $\mathrm{Sb}-\mathrm{C}$ rotations had the greatest activity and continuous potato the lowest activity of all rotations. After all plots were planted to potato, the $\mathrm{Sc}-\mathrm{C}$ and $\mathrm{Sb}-$ $\mathrm{C}$ rotations maintained higher activity than all other rotations and the Sc-Sb and P-P the lowest. Substrate richness, representing the number of carbon substrates effectively utilized, and substrate diversity, representing the evenness and diversity of substrate use (calculated as Shannon's index of diversity), tended to be higher following barley, canola, and sweet corn (in Sc-Sb) rotations, and lowest in the consecutive potato control after crops 1 and 2 of the rotation cycle (Fig. 2B and C). After potato crops, the Sb-C rotation maintained higher substrate richness than some rotations, and $\mathrm{Sb}-\mathrm{C}$ and $\mathrm{Sc}-\mathrm{C}$ higher substrate diversity than most other rotations.

Based on PCA of soil extract SU patterns, distinct quantitative and qualitative differences among cropping systems in their use of sole carbon sources after planting to crops 1 and 2 were evident (Fig. 3). After crop 1, the $\mathrm{B}-\mathrm{Cl}$ rotation had the most distinctive

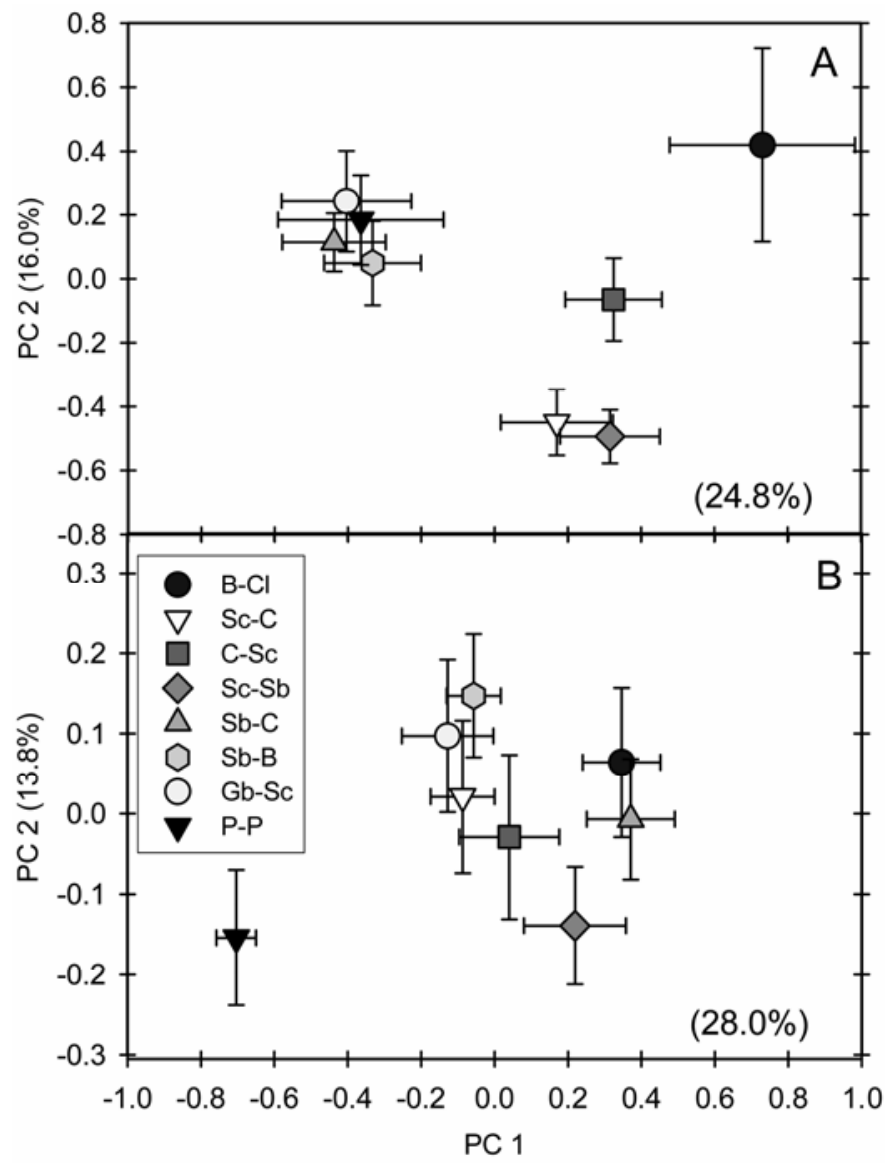

Fig. 3. Substrate utilization profiles of soil microbial communities following $\mathbf{A}$, rotation crop 1 and $\mathbf{B}$, rotation crop 2 from different 3 -year cropping systems as represented by principal components (PCs) 1 and 2 from $\mathrm{PC}$ analysis. Cropping systems (crop 1 and crop 2) consisted of $\mathrm{B}-\mathrm{Cl}=$ barley/cloverclover, $\mathrm{Sc}-\mathrm{C}=$ sweet corn-canola, $\mathrm{C}-\mathrm{Sc}=$ canola-sweet $\mathrm{corn}, \mathrm{Sc}-\mathrm{Sb}=$ sweet corn-soybean, $\mathrm{Sb}-\mathrm{C}=$ soybean-canola, $\mathrm{Sb}-\mathrm{B}=$ soybean-barley/clover, $\mathrm{Gb}-\mathrm{Sc}=$ green bean-sweet corn, and P-P = consecutive potato (control). All systems included potato as the third crop. Error bars represent the standard error of the mean. Numbers in parentheses refer to percentage of total variability accounted for by each PC for each cropping stage. Values represent combined data from spring soil samples collected from each of two field seasons for each cropping stage. 
profile, different from all others with higher values for PCs 1 and 2. Rotations with canola or sweet corn as crop 1 formed a second cluster group, and the rotations with soybean, green bean, or potato as crop 1 formed a third cluster group characterized by lower PC 1 values than the others (Fig. 3A). Several carbohydrates (including mannitol, cellobiose, lactose, $\beta$-methyl glucoside, and $N$-acetyl glucosamine), carboxylic acids (galacturonic, itaconic, and $\gamma$-hydroxybutyric acids), and amino acids (arginine, asparagine, and serine) were the substrates most responsible for differentiation along PCs 1 and 2, with higher values for PC 1 indicating greater utilization of these compounds, and higher values for PC 2 indicating greater carbohydrate use, but lower utilization of itaconic acid, asparagine, and serine. PCs 1 and 2 combined accounted for $40.8 \%$ and PCs 1 to 5 accounted for $66.4 \%$ of the total variability in SU profiles. After crop 2, the continuous potato control had SU characteristics distinct from all other rotations, with lower values for PCs 1 and 2 (Fig. 3B). The $\mathrm{B}-\mathrm{Cl}$ and $\mathrm{Sb}-\mathrm{C}$ rotations had the highest values for $\mathrm{PC} 1$ and were distinct from most other rotations. Some differences were observed among other rotations, primarily in PC 2, but there was also much overlap, with no distinct cluster groups identifiable. Differences in PC 1 were determined primarily by utilization of selected carbohydrates, such as lactose, $\beta$-methyl glucoside, and $\mathrm{N}$-acetyl glucosamine, with higher PC values indicating greater utilization. Values for PC 2, however, were determined primarily by differences in the utilization of malic acid and $\mathrm{N}$-acetyl glucosamine. PCs 1 and 2 accounted for $41.8 \%$ and PCs 1 to 5 accounted for $64.8 \%$ of the total variability in SU profiles. Differences in SU profiles among cropping systems were less pronounced and generally not significant (except for lower values for PCs in P-P plots) after all plots were planted to potato (data not shown).

FAME profiles. Based on PCA of fatty acid data, distinct differences in soil FAME profiles among the different cropping systems were observed, particularly after planting crops 1 and 2, with differences less apparent after planting to potato (Fig. 4). After crop 1, rotations with sweet corn ( $\mathrm{Sc}-\mathrm{C}$ and $\mathrm{Sc}-\mathrm{Sb}$ ) and $\mathrm{Sb}-$ $\mathrm{C}$ had higher $\mathrm{PC} 1$ values than the other rotations, and continuous potato had lower PC 1 values than all other rotations (Fig. 4A). Principal components 1 and 2 accounted for 50.7 and $14.8 \%$ of the variability, respectively, and PCs 1 to 5 accounted for $85.7 \%$ of the total variability in the fatty acid profiles. Saturated straight chain fatty acids 12:0 and 16:0, monounsaturated $17: 1 \omega 7 \mathrm{c}$ and 18:1 $\omega 9 \mathrm{c}$, and polyunsaturated 18:2 $\omega 6 \mathrm{c}$ were the primary fatty acids responsible for differentiation along PC 1; and 12:0, 16:1 $\omega 7 \mathrm{c}, 16: 1 \omega 5 \mathrm{c}, 17: 1 \omega 7 \mathrm{c}$, and $18: 1 \omega 9 \mathrm{c}$ were the primary fatty acids accounting for variability along PC 2 . After crop 2, cumulative effects of both rotation crops resulted in distinct differences among profiles of virtually all cropping systems (Fig. 4B). Rotations with sweet corn $(\mathrm{C}-\mathrm{Sc}, \mathrm{Gb}-\mathrm{Sc}$, and $\mathrm{Sc}-\mathrm{Sb})$ tended to have the highest values for PC 1, and those with canola as crop 2 (Sc-C and $\mathrm{Sb}-\mathrm{C}$ ) had the highest values for PC 2. Continuous potato resulted in the lowest values for PC 1 . Specific effects of different cropping sequences also were evident in FAME profiles after crop 2. For example, $\mathrm{C}-\mathrm{Sc}$ and $\mathrm{Sc}-\mathrm{C}$ rotations resulted in different profile characteristics, with Sc-C having high PC 2 values and $\mathrm{C}$ Sc having fairly high values for both PC 1 and 2. Also, sweet corn following green bean $(\mathrm{Gb}-\mathrm{Sc})$ resulted in different profile characteristics than when sweet corn followed canola (C-Sc), with C-Sc retaining higher PC 2 values associated with canola rotations (Fig. 2B). PCs 1 and 2 accounted for 38.5 and $17.0 \%$ of the variability, respectively, and PCs 1 to 5 accounted for $83.4 \%$ of the total variability in the FAME profiles. Monounsaturated fatty acid $16: 1 \omega 5 \mathrm{c}$ was the dominant fatty acid responsible for differentiation along PC 1 , whereas 18:1 $\omega 9 \mathrm{c}$ and 18:2 $\omega 6 \mathrm{c}$ were the primary fatty acids responsible for differentiation along PC 2. After the potato phase of the rotation, distinctly different profiles from all other rotations were observed for P-P, characterized by lower values for PC 1 (Fig. 4C). However, differences among most of the other rotations were no longer apparent, with variable and less distinct profiles produced by all rotations. The same groups of fatty acids that were important in explaining variability in PCs 1 and 2 in the previous cropping stages also were important in the potato phase.

Specific differences among rotations responsible for the distinctions observed in PCA of FAME profiles were made clearer by analysis of the fatty acid data by structural classes (Table 3 ) and the individual fatty acids accounting for the greatest variability in

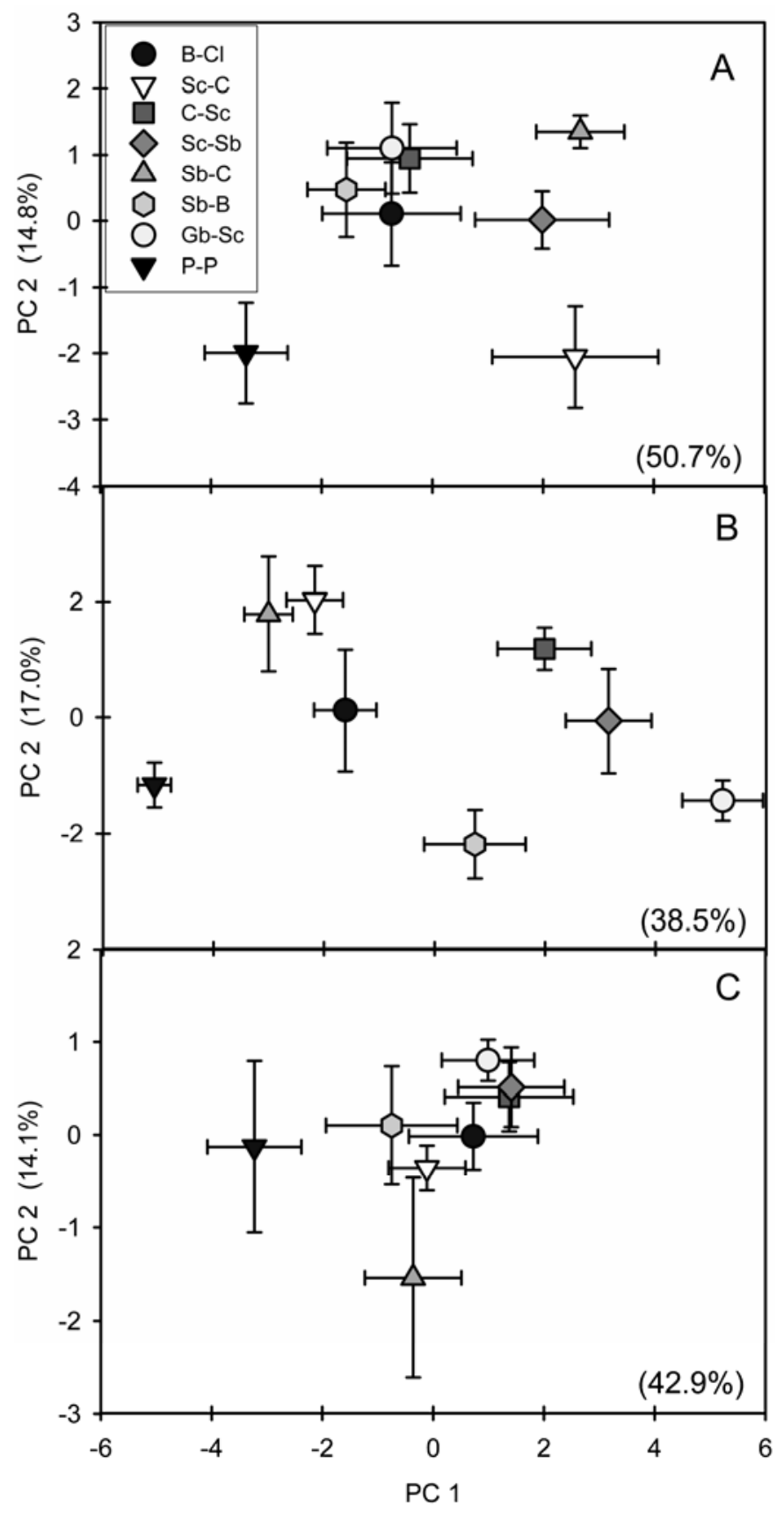

Fig. 4. Fatty acid profiles of soil microbial communities following $\mathbf{A}$, rotation crop 1, B, rotation crop 2, and $\mathbf{C}$, potato (crop 3) from different 3-year cropping systems as represented by principal components (PCs) 1 and 2 from PC analysis. Cropping systems (crop 1 and crop 2) consisted of $\mathrm{B}-\mathrm{Cl}=$ barley/cloverclover, Sc-C = sweet corn-canola, $\mathrm{C}-\mathrm{Sc}=$ canola-sweet corn, $\mathrm{Sc}-\mathrm{Sb}=$ sweet corn-soybean, $\mathrm{Sb}-\mathrm{C}=$ soybean-canola, $\mathrm{Sb}-\mathrm{B}=$ soybean-barley/clover, $\mathrm{Gb}-\mathrm{Sc}=$ green bean-sweet corn, and P-P = consecutive potato (control). All systems included potato as the third crop. Error bars represent the standard error of the mean. Numbers in parentheses refer to percentage of total variability accounted for by each PC for each cropping stage. 
PCA (Table 4). Overall, continuous potato resulted in higher proportions of the straight chain saturated class of fatty acids and lower amounts of monounsaturated fatty acids than all other rotations after crop 2, resulting in a lower ratio of monounsaturated to saturated fatty acids (Table 3). Most monounsaturates are associated mainly with gram-negative bacteria, but others (including $16: 1 \omega 5 \mathrm{c}$ and $18: 1 \omega 9 \mathrm{c}$ ) are associated with both bacteria and fungi. Continuous potato also resulted in lower proportions of polyunsaturated fatty acids, which are most closely associated with fungi, resulting in a lower ratio of fungal to bacterial fatty acids than several other rotations. On the other hand, after cropping to sweet corn, plots had the lowest levels of saturated fatty acids, highest proportions of monounsaturated fatty acids, and highest ratio of mono to saturated fatty acids. There were few differences detectable among cropping systems in the ratio of branched to hydroxy fatty acids, a general indicator of the relative proportions of gram-positive to gram-negative bacteria, at any sampling time (data not shown).

Additional differences among cropping systems were related to the proportions of specific fatty acids within the general structural classes, particularly the monounsaturated group (Table 4). For example, P-P nonrotation resulted in the lowest levels of $16: 1 \omega 7 \mathrm{c}$ and 16:1 $\omega 5 \mathrm{c}$ but the highest levels of 17:1 $\omega 7 \mathrm{c}$ and moderate levels of 18:1 $\omega 9 \mathrm{c}$ compared with the other rotations following planting to crop 2. Proportions of $16: 1 \omega 7 \mathrm{c}$ were highest after planting sweet corn and barley, and levels of 17:1 $\omega 7 \mathrm{c}$ were lowest after sweet corn. Proportions of monounsaturated 16:1 $\omega 5 \mathrm{c}$, which had the greatest differences among rotations, were greatest in $\mathrm{Gb}-\mathrm{Sc}$ plots, followed by $\mathrm{Sc}-\mathrm{Sb}$ and $\mathrm{C}-\mathrm{Sc}$, much lower follow- ing canola ( $\mathrm{Sc}-\mathrm{C}, \mathrm{Sb}-\mathrm{C})$, and lowest with continuous potato (Table 4). Proportions of 18:1 $\omega 9 \mathrm{c}$ were highest following sweet corn and canola crops and lowest in barley rotations ( $\mathrm{Sb}-\mathrm{B}$ and $\mathrm{B}-$ $\mathrm{Cl})$. Levels of 18:2 $\omega 6 \mathrm{c}$ tended to be highest in the $\mathrm{B}-\mathrm{Cl}$ rotation and lowest in the P-P control.

Soilborne potato disease and tuber yield. Diseases caused by $R$. solani, including stem and stolon canker on potato plants and black scurf on potato tubers, were the primary soilborne diseases observed in both 2000 and 2001. There also were some sporadic occurrences of common scab, but disease levels were low and not adequate for accurate assessment or differentiation among cropping systems. There were no indications or symptoms of any powdery scab, white mold, or Verticillium wilt in any field plants or on tubers collected. In the 2000 season, all crop rotations reduced the incidence and severity of black scurf on potato tubers relative to the P-P control (severity data comparable with incidence; data not shown), with Sb-B, Sb-C, C-Sc, and Sc-Sb providing the lowest levels of disease (Table 5). All rotations also reduced the proportion of misshapen tubers produced compared with the P-P control. Although total yield was not significantly different among rotations, the $\mathrm{Sb}-\mathrm{C}$ and $\mathrm{Sb}-\mathrm{B}$ rotations produced the nominally highest overall yields, averaging 9 to $12 \%$ higher than the continuous potato nonrotation. Differences in marketable yield (data not shown) also were not significant and showed trends similar to those of total yield. In 2001, all rotations except $\mathrm{B}-\mathrm{Cl}$ reduced the incidence and severity of stem canker lesions compared with the control, with the $\mathrm{Sb}-\mathrm{C}$ rotation also reducing severity compared with all other rotations. Severity of stolon canker also was reduced relative to the potato control with the $\mathrm{Sb}-\mathrm{C}, \mathrm{Sb}-\mathrm{B}, \mathrm{Sc}-\mathrm{C}$,

TABLE 3. Variation in composition of fatty acid structural classes (represented as percentage of total fatty acids) and class ratios for soil samples collected from different 3 -year cropping systems following planting of rotation crop $2^{\mathrm{y}}$

\begin{tabular}{|c|c|c|c|c|c|c|}
\hline \multirow[b]{2}{*}{ Rotation $^{\mathrm{z}}$} & \multicolumn{3}{|c|}{ Fatty acid classes $(\%)$} & \multicolumn{3}{|c|}{ Class ratios } \\
\hline & Saturated & Monounsaturated & Polyunsaturated & Mono/sat & Gram+/gram- & Fungi/bacteria \\
\hline $\mathrm{B}-\mathrm{Cl}$ & $23.7 \mathrm{ab}$ & $22.6 \mathrm{~d}$ & $9.93 \mathrm{a}$ & $0.96 \mathrm{~d}$ & $1.44 \mathrm{a}$ & $0.57 \mathrm{a}$ \\
\hline Sc-C & $23.6 \mathrm{ab}$ & $24.6 \mathrm{c}$ & $8.63 \mathrm{ab}$ & $1.05 \mathrm{~d}$ & $1.48 \mathrm{a}$ & $0.46 \mathrm{ab}$ \\
\hline $\mathrm{C}-\mathrm{Sc}$ & $21.3 \mathrm{c}$ & $29.2 \mathrm{~b}$ & $8.50 \mathrm{abc}$ & $1.38 \mathrm{~b}$ & $1.68 \mathrm{a}$ & $0.55 \mathrm{ab}$ \\
\hline $\mathrm{Sc}-\mathrm{Sb}$ & $23.4 \mathrm{ab}$ & $29.7 \mathrm{~b}$ & $7.56 \mathrm{bcd}$ & $1.27 \mathrm{c}$ & $1.76 \mathrm{a}$ & $0.46 \mathrm{ab}$ \\
\hline $\mathrm{Sb}-\mathrm{C}$ & $23.2 \mathrm{~b}$ & $23.6 \mathrm{~cd}$ & $8.24 \mathrm{bc}$ & $1.02 \mathrm{~d}$ & $1.46 \mathrm{a}$ & $0.46 \mathrm{ab}$ \\
\hline $\mathrm{Sb}-\mathrm{B}$ & $23.2 \mathrm{~b}$ & $24.2 \mathrm{~cd}$ & $8.35 \mathrm{abc}$ & $1.04 \mathrm{~d}$ & $1.44 \mathrm{a}$ & $0.45 \mathrm{bc}$ \\
\hline $\mathrm{Gb}-\mathrm{Sc}$ & $21.4 \mathrm{c}$ & $32.0 \mathrm{a}$ & $6.87 \mathrm{~cd}$ & $1.51 \mathrm{a}$ & $1.62 \mathrm{a}$ & $0.43 \mathrm{bc}$ \\
\hline P-P & $24.5 \mathrm{a}$ & $20.1 \mathrm{e}$ & $6.43 \mathrm{~d}$ & $0.82 \mathrm{e}$ & $1.61 \mathrm{a}$ & $0.34 \mathrm{c}$ \\
\hline
\end{tabular}

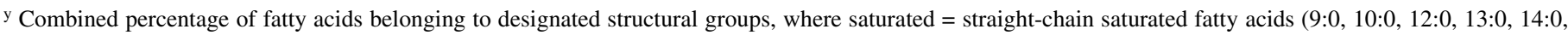
15:0, 16:0, and 18:0), Monounsaturated = monounsaturated fatty acids $(16: 1 \omega 7 \mathrm{c}, 16: 1 \omega 5 \mathrm{c}, 17: 1 \omega 7 \mathrm{c}, 17: 1 \omega 3 \mathrm{c}, 18: 1 \omega 9 \mathrm{c}$, and $18: 1 \omega 3 \mathrm{c})$, and polyunsaturated $=$ polyunsaturated fatty acids $(18: 3 \omega 6 \mathrm{c}$ and 18:2 $\omega 6 \mathrm{c})$. Ratios of specific classes that have significance as biomarkers for different organisms are listed as class ratios. Mono/sat = monounsaturated/saturated; Gram+/gram- = straight-chain branched fatty acids (11:0 iso, 13:0 iso, 13:0 ant, 14:0 iso, 15:0 iso, 15:0 ant, 16:0 iso, 17:0 iso, and 17:0 ant)/hydroxy fatty acids $(10: 03 \mathrm{OH}, 11: 0$ iso $3 \mathrm{OH}, 12: 02 \mathrm{OH}, 12: 03 \mathrm{OH}, 15: 0 \mathrm{iso} 3 \mathrm{OH}, 16: 02 \mathrm{OH} 16: 03 \mathrm{OH}$, and 17:0 3OH); and Fungi/bacteria $=$ polyunsaturated/(branched + hydroxy). Means within columns followed by the same letter are not significantly different according to Fisher's protected least significant difference at $P=0.05$.

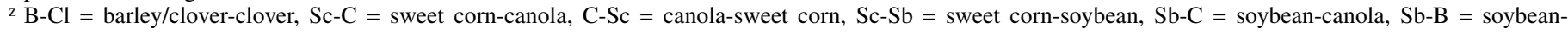
barley/clover, $\mathrm{Gb}-\mathrm{Sc}=$ green bean-sweet corn, and $\mathrm{P}-\mathrm{P}=$ consecutive potato (control).

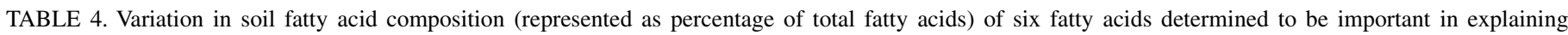
variability in principal components analyses among field plots in different cropping systems following planting to rotation crop 2

\begin{tabular}{|c|c|c|c|c|c|c|}
\hline \multirow[b]{2}{*}{ Rotation $^{\mathrm{y}}$} & \multicolumn{6}{|c|}{ Individual fatty acids $(\%)^{\mathrm{z}}$} \\
\hline & $12: 0$ & $16: 1 \omega 7 \mathrm{c}$ & $16: 1 \omega 5 \mathrm{c}$ & $17: 1 \omega 7 \mathrm{c}$ & $18: 1 \omega 9 \mathrm{c}$ & $18: 2 \omega 6 \mathrm{c}$ \\
\hline $\mathrm{B}-\mathrm{Cl}$ & $6.61 \mathrm{a}$ & $6.98 \mathrm{ab}$ & $4.25 \mathrm{~d}$ & $4.87 \mathrm{bc}$ & $1.80 \mathrm{bc}$ & $7.11 \mathrm{a}$ \\
\hline Sc-C & $6.26 \mathrm{ab}$ & $6.55 \mathrm{~b}$ & $3.26 \mathrm{de}$ & $5.05 \mathrm{ab}$ & $4.87 \mathrm{a}$ & $6.00 \mathrm{ab}$ \\
\hline $\mathrm{C}-\mathrm{Sc}$ & $5.68 \mathrm{~b}$ & $7.75 \mathrm{a}$ & $7.19 \mathrm{c}$ & $4.43 \mathrm{c}$ & $5.27 \mathrm{a}$ & $5.53 \mathrm{bc}$ \\
\hline $\mathrm{Sc}-\mathrm{Sb}$ & $6.24 \mathrm{ab}$ & $6.85 \mathrm{~b}$ & $8.78 \mathrm{~b}$ & $4.73 \mathrm{bc}$ & $4.54 \mathrm{a}$ & $4.96 \mathrm{bc}$ \\
\hline $\mathrm{Sb}-\mathrm{C}$ & $6.32 \mathrm{ab}$ & $5.75 \mathrm{c}$ & $2.66 \mathrm{e}$ & $4.85 \mathrm{bc}$ & $5.30 \mathrm{a}$ & $5.33 \mathrm{bc}$ \\
\hline $\mathrm{Sb}-\mathrm{B}$ & $6.23 \mathrm{ab}$ & $6.97 \mathrm{ab}$ & $7.01 \mathrm{c}$ & $4.71 \mathrm{bc}$ & $0.80 \mathrm{c}$ & $5.43 \mathrm{bc}$ \\
\hline $\mathrm{Gb}-\mathrm{Sc}$ & $5.63 \mathrm{~b}$ & $6.96 \mathrm{ab}$ & $11.15 \mathrm{a}$ & $4.50 \mathrm{c}$ & $4.34 \mathrm{a}$ & $4.07 \mathrm{~cd}$ \\
\hline P-P & $6.51 \mathrm{a}$ & $4.93 \mathrm{~d}$ & $1.38 \mathrm{f}$ & $5.28 \mathrm{a}$ & $2.68 \mathrm{~b}$ & $2.95 \mathrm{~d}$ \\
\hline
\end{tabular}

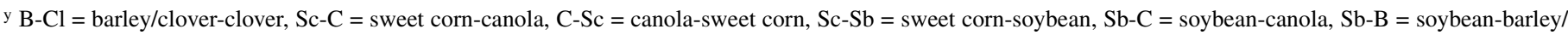
clover, $\mathrm{Gb}-\mathrm{Sc}=$ green bean-sweet corn, and $\mathrm{P}-\mathrm{P}=$ consecutive potato (control).

${ }^{\mathrm{z}}$ Means within columns followed by the same letter are not significantly different according to Fisher's protected least significant difference at $P=0.05$. 
and $\mathrm{Gb}-\mathrm{Sc}$ rotations. Incidence and severity of black scurf on tubers was reduced following canola, barley, and sweet corn rotations, with disease levels lower in the $\mathrm{Sb}-\mathrm{C}$ rotation than with several other rotations (Table 5). All rotations again reduced the percentage of misshapen tubers relative to the P-P control, with the $\mathrm{Sb}-\mathrm{C}$ rotation exhibiting the greatest reduction. Due to drought conditions in the field in July and August, which are the critical times for tuber formation and tuber bulking, potato yields were much lower in 2001 compared with 2000 and variable across rotations. Highest yield was obtained in the $\mathrm{B}-\mathrm{Cl}$ rotation and lowest in the Gb-Sc and P-P control.

Correlation analyses of microbial parameters and potato production parameters (disease and yield) for each potato year and both years together suggested associations among the various factors. Over both years, most microbial parameters, including microbial populations and activity, substrate richness and diversity, and PCs from SU and FAME profile analyses, were negatively correlated with the percentage of misshapen tubers produced, with substrate diversity and the ratio of monounsaturated to saturated fatty acids having the highest negative correlations
(Table 6). In 2000 but not in 2001 or in the combined data from both years, the incidence and severity of black scurf was negatively correlated with FAME PCs $(r=-0.48,-0.31$, and -0.38 for PCs 1 to 3, respectively), the ratio of monounsaturates to saturates $(r=-0.50)$, and SU PCs 1 and $3(r=-0.32$ and -0.40 , respectively). Total and marketable yield were negatively correlated with scurf incidence and the ratio of monounsaturated to saturated fatty acids and positively correlated with fungal populations, but no other microbial parameters, over both years. Total yield was correlated with microbial activity (AWCD) $(r=0.44)$, substrate richness $(r=0.46)$, and SU PCs 1,2 , and $4(r=0.41,0.30$, and 0.50 , respectively) in 2000, but not in 2001. Relative proportions of several individual fatty acids also were correlated with disease and yield parameters in one or both years. Levels of $16: 1 \omega 5 \mathrm{c}$, $16: 1 \omega 7 \mathrm{c}$, and $18: 2 \omega 6 \mathrm{c}$ were negatively correlated $(r=-0.34$ to $-0.37)$ and $18: 3 \omega 6 \mathrm{c}$ positively correlated $(r=-0.36)$ with scurf incidence in 2000, and 10:0 $3 \mathrm{OH}$ and 13:0 ant negatively correlated ( $r=-0.34$ and -0.43 , respectively) and $16: 1 \omega 7 \mathrm{c}$ and 16:0 positively correlated $(r=0.35$ and 0.36$)$ with scurf incidence in 2001. When data were combined over both years, 10:0 3OH

TABLE 5. Effects of different 3-year cropping systems on soilborne disease symptoms (stem or stolon canker [SSC] and black scurf [BS] caused by Rhizoctonia solani), tuber quality, and yield in 2000 and $2001^{\mathrm{x}}$

\begin{tabular}{|c|c|c|c|c|c|c|c|c|c|}
\hline \multirow[b]{2}{*}{ Rotation $^{\mathrm{y}}$} & \multicolumn{3}{|c|}{2000} & \multicolumn{6}{|c|}{2001} \\
\hline & BS incd. (\%) & Yield (Mg/ha) & Mis. (\%) & SSC incd. (\%) & SSC stem sev. ${ }^{\mathrm{z}}$ & SSC stolon sev. ${ }^{\mathrm{z}}$ & BS incd. (\%) & Yield (Mg/ha) & Mis. (\%) \\
\hline $\mathrm{Sb}-\mathrm{C}$ & $3.2 \mathrm{~b}$ & $32.5 \mathrm{a}$ & $9.6 \mathrm{~b}$ & $5.0 \mathrm{~b}$ & $0.43 \mathrm{c}$ & $0.41 \mathrm{c}$ & $14.1 \mathrm{~d}$ & $11.8 \mathrm{ab}$ & $1.7 \mathrm{c}$ \\
\hline Sb-B & $0.2 \mathrm{~b}$ & $31.5 \mathrm{a}$ & $5.7 \mathrm{bc}$ & $7.5 \mathrm{~b}$ & $0.73 \mathrm{~b}$ & $0.86 \mathrm{~b}$ & $25.6 \mathrm{bcd}$ & $11.6 \mathrm{ab}$ & $9.3 \mathrm{~b}$ \\
\hline $\mathrm{Sc}-\mathrm{C}$ & $5.6 \mathrm{~b}$ & $30.5 \mathrm{a}$ & $5.5 \mathrm{bc}$ & $10.0 \mathrm{~b}$ & $0.70 \mathrm{~b}$ & $0.73 \mathrm{bc}$ & $26.6 \mathrm{bcd}$ & $15.4 \mathrm{ab}$ & $4.0 \mathrm{bc}$ \\
\hline $\mathrm{Gb}-\mathrm{Sc}$ & $4.4 \mathrm{~b}$ & $30.3 \mathrm{a}$ & $7.6 \mathrm{bc}$ & $7.5 \mathrm{~b}$ & $0.75 \mathrm{~b}$ & $0.75 \mathrm{bc}$ & $21.1 \mathrm{~cd}$ & $9.5 \mathrm{~b}$ & $4.2 \mathrm{bc}$ \\
\hline C-Sc & $1.5 \mathrm{~b}$ & $28.0 \mathrm{a}$ & $7.3 \mathrm{bc}$ & $7.5 \mathrm{~b}$ & $0.65 \mathrm{~b}$ & $0.76 \mathrm{ab}$ & $34.7 \mathrm{abc}$ & $12.8 \mathrm{ab}$ & $4.6 \mathrm{bc}$ \\
\hline $\mathrm{Sc}-\mathrm{Sb}$ & $2.2 \mathrm{~b}$ & $28.0 \mathrm{a}$ & $2.6 \mathrm{c}$ & $10.0 \mathrm{~b}$ & $0.78 \mathrm{~b}$ & $0.89 \mathrm{ab}$ & $47.2 \mathrm{a}$ & $12.6 \mathrm{ab}$ & $2.6 \mathrm{c}$ \\
\hline $\mathrm{B}-\mathrm{Cl}$ & $8.8 \mathrm{~b}$ & $28.7 \mathrm{a}$ & $3.0 \mathrm{c}$ & $25.0 \mathrm{a}$ & $1.03 \mathrm{a}$ & $0.96 \mathrm{ab}$ & $42.5 \mathrm{ab}$ & $16.7 \mathrm{a}$ & $6.1 \mathrm{bc}$ \\
\hline P-P & $40.3 \mathrm{a}$ & $29.0 \mathrm{a}$ & $21.0 \mathrm{a}$ & $25.0 \mathrm{a}$ & $1.03 \mathrm{a}$ & $1.14 \mathrm{a}$ & $48.7 \mathrm{a}$ & $10.2 \mathrm{ab}$ & $18.8 \mathrm{a}$ \\
\hline
\end{tabular}

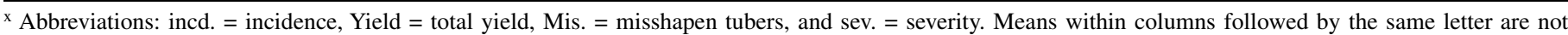
significantly different according to Fisher's protected least significant difference at $P=0.05$.

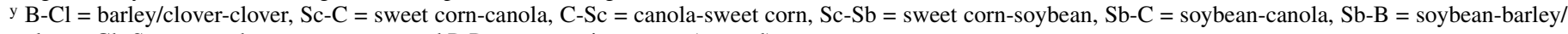
clover, $\mathrm{Gb}-\mathrm{Sc}=$ green bean-sweet corn, and $\mathrm{P}-\mathrm{P}=$ consecutive potato (control).

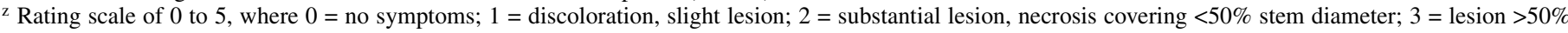
stem diameter; 4 = lesion girdling stem $(100 \%)$; and $5=$ stem girdled, plant dead.

TABLE 6. Correlation $(r)$ of selected soil microbial parameters with each other and with potato disease and yield estimates over two field seasons and all cropping systems ${ }^{\mathrm{y}}$

\begin{tabular}{|c|c|c|c|c|c|c|c|c|c|c|c|c|c|c|c|c|c|c|}
\hline Factor $^{\mathrm{Z}}$ & $\begin{array}{l}\text { Bact } \\
\text { pop }\end{array}$ & $\begin{array}{c}\text { Pseud } \\
\text { pop }\end{array}$ & $\begin{array}{c}\text { Fungi } \\
\text { pop }\end{array}$ & AWCD & $\begin{array}{l}\text { SU } \\
\text { rich }\end{array}$ & $\begin{array}{l}\text { SU } \\
\text { divr }\end{array}$ & $\begin{array}{l}\mathrm{SU} \\
\mathrm{PC} 1\end{array}$ & $\begin{array}{c}\text { SU } \\
\text { PC2 }\end{array}$ & $\begin{array}{l}\mathrm{SU} \\
\mathrm{PC} 3\end{array}$ & $\begin{array}{c}\text { FAME } \\
\text { PC1 }\end{array}$ & $\begin{array}{c}\text { FAME } \\
\text { PC2 }\end{array}$ & $\begin{array}{l}\text { Mono/ } \\
\text { sat }\end{array}$ & $\begin{array}{c}\text { Gram+l } \\
\text { gram- }\end{array}$ & $\begin{array}{c}\text { Fungi/ } \\
\text { bact }\end{array}$ & $\begin{array}{c}\text { Scurf } \\
\%\end{array}$ & $\begin{array}{c}\text { Miss } \\
\%\end{array}$ & $\begin{array}{l}\text { Total } \\
\text { yield }\end{array}$ & $\begin{array}{l}\text { Mkt } \\
\text { yield }\end{array}$ \\
\hline Bact pop & & $\ldots$ & $\ldots$ & $\ldots$ & $\ldots$ & $\ldots$ & $\ldots$ & $\ldots$ & $\ldots$ & $\ldots$ & $\ldots$ & $\ldots$ & $\ldots$ & $\ldots$ & $\ldots$ & $\ldots$ & $\ldots$ & $\ldots$ \\
\hline Pseud pop & 0.72 & $\ldots$ & $\ldots$ & $\ldots$ & $\ldots$ & $\ldots$ & $\ldots$ & $\ldots$ & $\ldots$ & $\ldots$ & $\ldots$ & $\ldots$ & $\ldots$ & $\ldots$ & $\ldots$ & $\ldots$ & $\ldots$ & $\ldots$ \\
\hline Fungi pop & $\mathrm{ns}$ & $\mathrm{ns}$ & $\ldots$ & $\ldots$ & $\ldots$ & $\ldots$ & $\ldots$ & $\ldots$ & $\ldots$ & $\ldots$ & $\ldots$ & $\ldots$ & $\ldots$ & $\ldots$ & $\ldots$ & $\ldots$ & $\ldots$ & $\ldots$ \\
\hline AWCD & 0.44 & 0.75 & ns & $\ldots$ & $\ldots$ & $\ldots$ & $\ldots$ & $\ldots$ & $\ldots$ & $\ldots$ & $\ldots$ & $\ldots$ & $\ldots$ & $\ldots$ & $\ldots$ & $\ldots$ & $\ldots$ & $\ldots$ \\
\hline SU rich & 0.45 & 0.72 & -0.27 & 0.92 & $\ldots$ & $\ldots$ & $\ldots$ & $\ldots$ & $\ldots$ & $\ldots$ & $\ldots$ & $\ldots$ & $\ldots$ & $\ldots$ & $\ldots$ & $\ldots$ & $\ldots$ & $\ldots$ \\
\hline SU divr & 0.34 & 0.50 & -0.55 & 0.56 & 0.65 & $\ldots$ & $\ldots$ & $\ldots$ & $\ldots$ & $\ldots$ & $\ldots$ & $\ldots$ & $\ldots$ & $\ldots$ & $\ldots$ & $\ldots$ & $\ldots$ & $\ldots$ \\
\hline SU PC1 & 0.35 & 0.69 & ns & 0.91 & 0.82 & 0.50 & $\ldots$ & $\ldots$ & $\ldots$ & $\ldots$ & $\ldots$ & $\ldots$ & $\ldots$ & $\ldots$ & $\ldots$ & $\ldots$ & $\ldots$ & $\ldots$ \\
\hline SU PC2 & ns & $\mathrm{ns}$ & ns & 0.26 & 0.26 & 0.29 & $\mathrm{~ns}$ & $\ldots$ & $\ldots$ & $\ldots$ & $\ldots$ & $\ldots$ & $\ldots$ & $\ldots$ & $\ldots$ & $\ldots$ & $\ldots$ & $\ldots$ \\
\hline SU PC3 & 0.26 & 0.30 & $\mathrm{~ns}$ & 0.45 & 0.25 & $\mathrm{~ns}$ & 0.28 & $\mathrm{~ns}$ & $\ldots$ & $\ldots$ & $\ldots$ & $\ldots$ & $\ldots$ & $\ldots$ & $\ldots$ & $\ldots$ & $\ldots$ & $\ldots$ \\
\hline FAME PC1 & $\mathrm{ns}$ & $\mathrm{ns}$ & -0.28 & 0.29 & 0.33 & 0.42 & 0.29 & $\mathrm{~ns}$ & $\mathrm{~ns}$ & $\ldots$ & $\ldots$ & $\ldots$ & $\ldots$ & $\ldots$ & $\ldots$ & $\ldots$ & $\ldots$ & $\ldots$ \\
\hline FAME PC2 & $\mathrm{ns}$ & ns & -0.32 & ns & $\mathrm{ns}$ & 0.26 & $\mathrm{~ns}$ & $\mathrm{~ns}$ & $\mathrm{~ns}$ & $\mathrm{~ns}$ & $\ldots$ & $\ldots$ & $\ldots$ & $\ldots$ & $\ldots$ & $\ldots$ & $\ldots$ & $\ldots$ \\
\hline Mono/sat & $\mathrm{ns}$ & $\mathrm{ns}$ & -0.34 & $\mathrm{~ns}$ & 0.26 & 0.38 & ns & $\mathrm{ns}$ & $\mathrm{ns}$ & 0.72 & $\mathrm{~ns}$ & $\ldots$ & $\ldots$ & $\ldots$ & $\ldots$ & $\ldots$ & $\ldots$ & $\ldots$ \\
\hline Gram+/gram- & ns & $\mathrm{ns}$ & ns & 0.23 & $\mathrm{~ns}$ & $\mathrm{~ns}$ & $\mathrm{~ns}$ & ns & $\mathrm{ns}$ & $\mathrm{ns}$ & $\mathrm{ns}$ & ns & $\ldots$ & $\ldots$ & $\ldots$ & $\ldots$ & $\ldots$ & $\ldots$ \\
\hline Fungi/bact & 0.28 & $\mathrm{~ns}$ & $\mathrm{~ns}$ & $\mathrm{~ns}$ & 0.25 & 0.35 & ns & $\mathrm{ns}$ & ns & 0.26 & 0.42 & 0.24 & 0.53 & $\ldots$ & $\ldots$ & $\ldots$ & $\ldots$ & $\ldots$ \\
\hline Scurf \% & ns & ns & ns & ns & ns & ns & ns & ns & ns & ns & $\mathrm{ns}$ & ns & ns & ns & $\ldots$ & $\ldots$ & $\ldots$ & $\ldots$ \\
\hline Miss \% & -0.26 & -0.31 & 0.44 & -0.27 & -0.29 & -0.64 & -0.32 & ns & -0.30 & -0.43 & -0.28 & -0.47 & $\mathrm{~ns}$ & -0.32 & 0.28 & $\ldots$ & $\ldots$ & $\ldots$ \\
\hline Total yield & ns & -0.26 & 0.27 & ns & -0.34 & ns & ns & ns & $\mathrm{ns}$ & $\mathrm{ns}$ & $\mathrm{ns}$ & -0.40 & ns & ns & -0.52 & ns & $\ldots$ & $\ldots$ \\
\hline Mkt yield & $\mathrm{ns}$ & ns & 0.27 & ns & ns & ns & ns & ns & ns & ns & $\mathrm{ns}$ & -0.39 & ns & $\mathrm{ns}$ & -0.21 & $\mathrm{~ns}$ & 0.86 & $\ldots$ \\
\hline
\end{tabular}

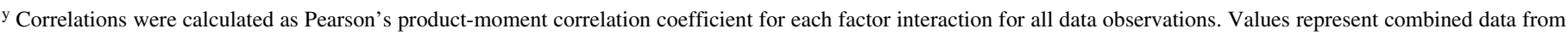
soil samples collected in the spring of both potato planting years (2000 and 2001) and correlated with disease and yield data for each respective year for each cropping system. Values presented are significant at $P=0.05$ and $\mathrm{ns}=$ not significant at $P=0.05$.

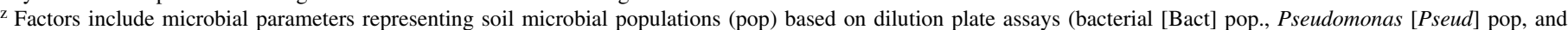
fungi pop), substrate utilization (SU) assays for microbial activity, substrate richness (rich), substrate diversity (divr), and principal components (PCs) analysis of SU profiles (average well color development [AWCD], SU rich, SU divr, SU PC1, SU PC2, and SU PC3, respectively), PC analysis of fatty acid methyl ester (FAME) profiles (FAME PC1 and FAME PC2), and FAME biomarkers representing the ratios of monounsaturated to saturated fatty acids (mono/sat), gram-positive to gram-negative bacteria (Gram+/gram-), and fungi to bacteria abundance (Fungi/bact). Disease and yield parameters include the incidence of black scurf on tubers (Scurf \%), the percentage of severely misshapen tubers (Miss \%), total tuber weight (Total yield), and marketable tuber weight (tubers $>114 \mathrm{~g}$ ) (Mkt yield). 
and 13:0 ant were positively correlated ( $r=0.32$ to 0.40$)$ and $16: 1$ $\omega 5 \mathrm{c}$ and $16: 1 \omega 7 \mathrm{c}$ negatively correlated ( $r=-0.44$ to -0.56$)$ with total and marketable yield. Within the microbial parameters, many were correlated to some degree with each other, with the highest correlations being among AWCD, substrate richness, SU PC 1, and Pseudomonas populations, as well as the monounsaturated/ saturated ratio being correlated highly with FAME PC 1 (Table 6).

\section{DISCUSSION}

Cropping systems resulted in distinct differences in soil microbial community characteristics directly associated with specific rotation crops and cropping sequences. Microbial characteristics often were observed to change dramatically from one cropping season to the next and were influenced primarily by the immediate preceding crop. In addition, cumulative effects due to a particular cropping sequence also were evident following the second of two rotation crops. Thus, both the specific rotation crop and the cropping sequence were important in shaping the soil microbial characteristics. These results demonstrate the strong influence crops have on soil microbial organisms, activity, and processes. Although numerous studies have reported on the direct influence of different plant species on rhizosphere communities $(23,30-32)$, there are relatively few studies that document the effects of specific crop rotations on changes in microbial communities in bulk soil, which may better reflect potential effects on subsequent crops (25). Lupwayi et al. (29) observed that microbial diversity was greater under wheat that was preceded by red clover green manure or field pea than under wheat following wheat or summer fallow. In cropping studies in Finland, eight different crops grown over three field seasons significantly affected microbial functional diversity as estimated by enzyme profiles, but had little effect on PLFA profiles, which were stable throughout the study (43). Comparing rhizoplane communities from different plants grown in soil from cereal-legume rotations versus continuous cereal, Alvy et al. (1) determined that cropping system greatly affected microbial community structure and species composition. However, Buyer et al. (7) suggested that plant effects were much less important than the effects of soil properties on microbial community structure, and that, in their studies, plant rhizosphere effects generally did not result in detectable changes to community structure of bulk soil. In general, cropped soil supports higher microbial biomass and diversity than fallow soil, with grain crops (wheat, barley, and oat) tending to support greater biomass than many other crops (such as potato), but diversified rotations often result in higher biomass than continuous grain (such as wheat) $(4,12,47,48)$.

In the research presented here, the overall effects of specific rotation crops on soil microbial characteristics confirmed and corroborated results reported in a previous cropping systems study using these same crops in 2-year rotations at a different location (25). In both studies, most rotations resulted in greater overall bacterial populations and greater microbial activity than planting consecutive potato crops. Inclusion of barley and canola in the rotation generally resulted in greater overall bacterial biomass, often even when all plots were planted to potato. In addition, higher populations of microorganisms that generally are beneficial to plants, such as Pseudomonas spp. and Trichoderma spp., also were observed after planting barley, canola, and sweet corn crops. SU analyses indicated that certain rotations, including those containing barley, canola, and sweet corn, tended to result in higher overall SU (activity), substrate diversity, and substrate richness, whereas soybean and potato tended toward lower substrate richness and diversity. Grayston et al. (19), also using SU techniques, differentiated rhizosphere communities of wheat from those of ryegrass, bentgrass, and clover, based primarily on increased utilization of selected carbohydrates and amino acids.
In addition to demonstrating or confirming the microbial effects of specific rotation crops, this research also documented the effects that different cropping sequences (with multiple rotation crops) can have on soil microbial communities. Thus, although the immediate preceding crop was most important in influencing soil microbial characteristics, the combination and sequence of multiple rotation crops also produced significant effects and resulted in distinctive microbial profiles. Therefore, a C-Sc rotation did not have the same overall effects as a $\mathrm{Sc}-\mathrm{C}$ rotation, and a $\mathrm{C}$ $\mathrm{Sc}$ and a Gb-Sc rotation may have very different microbial characteristics even though both feature a sweet corn crop prior to potato (Fig. 4B). Though this result is not unexpected, there is little documentation of specific microbial effects due to different cropping sequences within rotation systems.

As in our previous cropping systems study (25), distinct differences in fatty acid profiles were detected for all cropping systems. These differences were identified using principal components analyses and detailed in the proportions of structural classes, biomarkers, and individual fatty acids present under each cropping system. The proportions of saturated and unsaturated (mono- and polyunsaturated) fatty acids, in particular, have been proposed as important indicators of microbial communities. The monounsaturates, produced mainly by gram-negative organisms (and some fungi), increase with organic matter content and high substrate availability and decrease with flooding and other anaerobic conditions $(3,4,47,48)$. The ratio of monounsaturated to saturated fatty acids has been used to evaluate communities and environmental conditions $(47,48)$, with observed ratios of $>1$ for grassland and cultivated soils with high $\mathrm{C}$ content and organic inputs, $\approx 1$ for other cultivated soils, and $<1$ for soils characterized by low-substrate, low-organic inputs. In our cropping systems, the monounsaturated/saturated ratio was highest following sweet corn (1.3 to 1.5 ), $\approx 1.0$ following most other crops, and 0.8 for continuous potato rotations. These values are consistent with those of Zelles et al. $(47,48)$ and Larkin $(25)$ and underscore the effects of rotation versus continuous potato cropping.

The polyunsaturated fatty acids (represented primarily by 18:2 $\omega 6 \mathrm{c})$ are associated mainly with fungi, whereas branched and hydroxy fatty acids are most representative of gram-positive and gram-negative bacteria, respectively. The fungi/bacteria ratio provides an indication of these relative populations among rotations, and the $\mathrm{B}-\mathrm{Cl}$ rotation generally had higher ratios compared with other rotations, whereas P-P had the lowest. In other studies, high levels of polyunsaturates have been associated with high organic matter or low $\mathrm{pH}$ soils $(4,45)$. Although the indication of low fungal populations in the continuous potato control by the FAME data appears to contradict the dilution plating results, as mentioned previously, the high fungal populations detected in potato plots by dilution plating was primarily the result of stimulation of a single fungus, a Penicillium sp. This fungus likely was present mainly as vast numbers of dormant conidia, which were enumerated in plate counts, but the organism was not actively growing in the soil and apparently did not affect fatty acid profiles. The FAME profile data may more accurately reflect actual fungal populations in these soils. Although the role or importance of the Penicillium sp. found associated with potato in this study, as well as in our previous rotation study at a different location (25), is not yet known, ongoing research has indicated that the organism is not a potato pathogen and may have some biological control activity against $R$. solani (5).

The fatty acid $16: 1 \omega 5 \mathrm{c}$ is known to be a major component of arbuscular mycorrhizal (AM) fungi (18), and has been proposed as a valuable biomarker for estimating AM biomass and distribution (34). Although 16:1 $\omega 5 \mathrm{c}$ also is a minor component of a select group of bacteria, changes in soil levels of this fatty acid with various management practices have been consistent with effects on AM fungi, including increases with manure and organic amendments $(4,35)$, crop rotations (25), liming (15), and reduc- 
tions associated with tillage (12) and additions of heavy metals (15). In this study, levels of $16: 1 \omega 5 \mathrm{c}$ were affected greatly by cropping system, with significant differences among cropping systems at all cropping stages, and this fatty acid was the single greatest contributor in differentiating PCs after planting crop 2 . Planting sweet corn increased levels of this fatty acid whereas planting potato drastically reduced its presence, which may indicate (subject to verification) differing levels of AM fungi among the cropping systems. Another monounsaturate that may represent a particular subgroup of bacteria, 17:1 $\omega 7 \mathrm{c}$, was observed to be higher following potato and lower following sweet corn. Larkin et al. (27) observed this fatty acid to decrease following manure amendments in incubation studies. Another monounsaturate, 18:1 $\omega 9 \mathrm{c}$, which is a component of fungi as well as certain gramnegative bacteria, in general, increased following canola and sweet corn crops and decreased following barley. Peacock et al. (35) and Larkin et al. (27) observed this fatty acid to increase after manure and organic amendments. Cumulative effects of the different cropping systems with different combinations and sequences also were apparent, particularly in the FAME profiles and the relative composition of specific fatty acids after crop 2 , indicating the importance of crop sequence and placement within the cropping system.

With respect to Rhizoctonia diseases, the incidence and severity of black scurf was greater across all rotations in 2001 versus 2000, despite drought conditions for much of the summer of 2001. This occurrence is most likely explained by the timing of the rainfall events that season. Although drought conditions persisted through July and August (critical times for tuber formation and bulking), substantial rainfall occurred in early to mid-September (time of vine killing, skin set, and harvest). Black scurf forms on tubers primarily in the period between vine killing and harvest; therefore, the suddenly wet conditions may have stimulated growth and activity of $R$. solani, resulting in increased scurf formation on tubers in that year. The 2001 potato crop also represented the second potato crop in the rotation cycle (also planted to potato in 1998), which also may account for the higher disease levels observed in most rotations in 2001 relative to 2000.

All cropping systems reduced Rhizoctonia diseases (both plant and tuber symptoms) to some degree relative to the continuous potato control, with disease levels generally lower following barley or canola crops, and lowest in the Sb-C rotation. Cropping systems with clover or soybean directly preceding potato were not as effective, resulting in levels of scurf comparable with the continuous potato control in 2001. In previous greenhouse trials assessing individual rotation crop effects on Rhizoctonia inoculum and disease, clover resulted in high populations of $R$. solani, comparable with those planted to potato, and Rhizoctonia diseases on subsequently planted potato also were higher than with other rotation crops (42). In addition, canker symptoms were observed on clover roots under some conditions, indicating that red clover may act as a host of $R$. solani. Thus, soybean and clover may best be used in these cropping systems when not immediately preceding potato. When soybean was followed by barley or canola prior to the potato crop, low disease levels were maintained, indicating that potentially higher levels of Rhizoctonia disease associated with soybean rotations may be a problem only when potato directly follows soybean. All rotations also reduced the percentage of misshapen tubers relative to the P-P control in both years, reflecting the overall improved quality of tubers following crop rotations. Various 2-year crop rotations, including ryegrass, oat, vetch, barley, and canola, previously have been shown to be helpful in the reduction of inoculum of $R$. solani as well as disease incidence on potato plants and tubers $(22,26$, 40,44).

Although significant yield effects due to cropping system were not observed in this study, there were trends that indicated that cropping system could have an effect. A poor harvest year in 2001 made it difficult to adequately assess yield effects. Due to summer drought conditions, tuber yields were 42 to $69 \%$ lower across all rotations in 2001 compared with 2000, and any differences among cropping systems likely were drought related rather than resulting from soil microbiology or disease issues. For example, the slightly higher yield observed in the $\mathrm{B}-\mathrm{Cl}$ plots in 2001 probably was related to a better ability to hold water due to increased residue levels incorporated from this rotation. However, this rotation had high disease levels. In 2000, a more normal crop year, tuber yields were nominally higher ( 5 to $12 \%$ ) following canola or barley crops. Definite yield effects due to both cropping sequence and length of rotations have been shown in other research $(8$, $36,38,41)$.

Several microbial parameters, including SU and FAME characteristics, were correlated somewhat with disease and yield estimates, suggesting that the microbial characteristics are in some way associated with these effects. However, no single factor was highly correlated with disease or yield in both potato harvest years. The interactions among microbial community characteristics, soilborne diseases, crop productivity, and other factors are very complex, and there is no simple or straightforward microbial indicator directly related to crop health or crop production. Microbial communities can change in many different ways and any specific relationships between microbial characteristics and crop parameters are not yet known. For example, canola and sweet corn crops had very different effects on soil microbial communities (represented by FAME profiles), yet both crops resulted in the reduction of Rhizoctonia diseases in subsequent potato crops, essentially nullifying simple correlations between microbial characteristics and disease levels. Nonetheless, continued work to better understand how and what changes in soil microbial characteristics are associated with disease suppression and crop production should illuminate these relationships.

In conclusion, this research with 3-year cropping systems has confirmed and corroborated results observed in our previous cropping systems trial, which evaluated 2-year and limited 3-year rotations containing these same crops at a different field site located $\approx 320 \mathrm{~km}$ southwest of this field location (25), with both studies demonstrating distinctive changes in soil microbial communities (measurable by multiple approaches) associated with specific rotation crops. These similar responses over multiple studies and locations indicate that these effects on microbial community characteristics are consistent, detectable, and reproducible effects related to the specific cropping systems. In addition, this study has added substantially to this information by providing data on the effects of specific cropping sequences and the combined effects of multiple rotation crops in 3-year cropping systems, as well as showed significant differences and reductions in soilborne diseases due to these cropping systems. Thus, this research has documented significant changes in soil microbial community characteristics directly related to different rotation crops and sequences. By trying to relate changes in microbial community parameters with soilborne disease and crop productivity data, this research also has begun to assess the relationship between soil microbial community characteristics and plant health. Unfortunately, at this time, the precise meaning of these changes and their potential effects are not yet understood; however, by characterizing these systems and defining what the effects are and what types of changes result in positive crop attributes (disease suppression, increased yield, increased sustainability, and so on), we can begin to develop manipulation of the soil microbial environment as a viable crop management strategy. Along these lines, we also are characterizing changes in soil microbial communities related to other management practices, such as tillage and additions of organic (residues, compost, and green manures) and biological (biocontrol organisms and microbial inoculants) amendments, to better understand how different management practices affect soil microbial communities, and how these effects may in 
turn affect disease development and crop productivity. The ultimate goal of this approach is the eventual implementation of crop management practices that will optimize the soil microbial environment for reduced disease, increased production, and long-term sustainability.

\section{ACKNOWLEDGMENTS}

Mention of trade names or commercial products in this article is solely for the purpose of providing specific information and does not imply recommendation or endorsement by the U.S. Department of Agriculture. We thank M. Brewer for her capable technical assistance on all aspects of this research, particularly the soil sampling and processing, soil dilution platings, substrate utilization assays, extraction and running of the fatty acid analyses, and disease assessments in the field; and D. Cowperthwaite for maintenance of the field plots and harvesting, weighing, and grading tubers.

\section{LITERATURE CITED}

1. Alvey, S., Yang, C. H., Buerkert, A., and Crowley, D. E. 2003. Cereal/ legume rotation effects on rhizosphere bacterial community structure in west African soils. Biol. Fertil. Soils 37:73-82.

2. Bailey, K. L., and Lazarovits, G. 2003. Suppressing soil-borne diseases with residue management and organic amendments. Soil Tillage Res. 72:169-180.

3. Bossio, D. A., and Scow, K. M. 1998. Impacts of carbon and flooding on soil microbial communities: Phospholipid fatty acid profiles and substrate utilization patterns. Microbial Ecol. 35:265-278.

4. Bossio, D. A., Scow, K. M., Gunapala, N., and Graham, K. J. 1998. Determinants of soil microbial communities: Effects of agricultural management, season, and soil type on phsopholipid fatty acid profiles. Microbial Ecol. 36:1-12.

5. Brewer, M. T., and Larkin, R. P. 2005. Efficacy of several potential biocontrol organisms against Rhizoctonia solani on potato. Crop Prot. 24:939-950.

6. Buyer, J. S., Roberts, D. P., and Russek-Cohen, E. 1999. Microbial community structure and function in the spermosphere as affected by soil and seed type. Can. J. Microbiol. 45:138-144.

7. Buyer, J. S., Roberts, D. P., and Russek-Cohen, E. 2002. Soil and plant effects on microbial community structure. Can. J. Microbiol. 48:955-964.

8. Carter, M. R., and Sanderson, J. B. 2001. Influence of conservation tillage and rotation length on potato productivity, tuber disease and soil quality parameters on a fine sandy loam in eastern Canada. Soil Tillage Res. 63:1-13.

9. Cavigelli, M. A., Robertson, G. P., and Klug, M. K. 1995. Fatty acid methyl ester (FAME) profiles as measures of soil microbial community structure. Plant Soil 170:99-113.

10. Curl, E., and Truelove, B. 1986. The Rhizosphere. Springer-Verlag, Berlin.

11. Davies, F. L., and Williams, S. T. 1970. Studies on the ecology of actinomycetes in soil. I. The occurrence and distribution of actinomycetes in a pine forest soil. Soil Biol. Biochem. 2:227-238.

12. Drijber, R. A., Doran, J. W., Parkhurst, A. M., and Lyon, D. J. 2000. Changes in soil microbial community structure with tillage under longterm wheat-fallow management. Soil Biol. Biochem. 32:1419-1430.

13. Fang, C., Radosevich, M., and Fuhrman, J. J. 2001. Characterization of rhizosphere microbial community structure in five similar grass species using FAME and BIOLOG analyses. Soil Biol. Biochem. 33:679-682.

14. Feng, Y., Motta, A. C., Reeves, D. W., Burmester, C. H., van Santern, E., and Osborne, J. A. 2003. Soil microbial communities under conventionaltill and no-till continuous cotton systems. Soil Biol. Biochem. 35:16931703.

15. Frostegård, A., Bååth, E., and Tunlid, A. 1993. Shifts in the structure of soil microbial communities in limed forests as revealed by phospholipid fatty acid analysis. Soil Biol. Biochem. 25:723-730.

16. Garland, J. L., and Mills, A. L. 1991. Classification and characterization of heterotrophic microbial communities on the basis of patterns of community-level sole-carbon-source utilization. Appl. Environ. Microbiol. 57:2351-2359.

17. Glimm, E., Heuer, H., Engelen, B., Smalla, K., and Backhaus, H. 1997. Statistical comparisons of community catabolic profiles. J. Microbiol. Methods 30:71-80.

18. Graham, J. H., Hodge, N. C., and Morton, J. B. 1995. Fatty acid methyl ester profiles for characterization of Glomalean fungi and their endomycorrhizae. Appl. Environ. Microbiol. 61:58-64.

19. Grayston, S. J., Wang, S., Campbell, C. D., and Edwards, A. C. 1998. Selecting influence of plant species on microbial diversity in the rhizosphere. Soil Biol. Biochem. 30:369-378.
20. Harch, B. D., Correll, R. L., Meech, W., Kirkby, C. A., and Pankhurst, C. E. 1997. Using the Gini coefficient with BIOLOG substrate utilisation data to provide an alternative quantitative measure for comparing bacterial soil communities. J. Microbiol. Methods 30:91-101.

21. Hoekstra, O. 1989. Results of twenty-four years of crop rotation research at 'De Schreef' experimental site. Pages 37-43 in: Effects of Crop Rotation on Potato Production in the Temperate Zones. J. Vos, C. D. Van Loon, and G. J. Bollen, eds. Kluwer Academic Publishers, Dordrecht, The Netherlands.

22. Honeycutt, C. W., Clapham, W. M., and Leach, S. S. 1996. Crop rotation and $\mathrm{N}$ fertilization effects on growth, yield, and disease incidence in potato. Am. Potato J. 73:45-61.

23. Ibekwe, A. M., and Kennedy, A. C. 1999. Fatty acid methyl ester (FAME) profiles as a tool to investigate community structure of two agricultural soils. Plant Soil 206:151-161.

24. Kandelar, E., Marschner, P., Tscherko, D., Gahoonia, T. S., and Nielsen, N. E. 2002. Microbial community composition and functional diversity in the rhizosphere of maize. Plant Soil 238:301-312.

25. Larkin, R. P. 2003. Characterization of soil microbial communities under different potato cropping systems by microbial population dynamics, substrate utilization, and fatty acid profiles. Soil Biol. Biochem. 35:1451-1466.

26. Larkin, R. P., and Honeycutt, C. W. 2002. Crop rotation effects on Rhizoctonia canker and black scurf of potato in central Maine, 1999 and 2000. Biol. Cult. Tests (online) Report 17:PT06. DOI: 10.1094/BC17.

27. Larkin, R. P., Honeycutt, C. W., and Griffin, T. S. Effect of swine and dairy manure amendments on microbial communities in three soils as influenced by environmental conditions. Biol. Fertil. Soils. (In press.)

28. Larkin, R. P., Hopkins, D. L., and Martin, F. N. 1993. Effect of successive watermelon plantings on Fusarium oxysporum and other microorganisms in soils suppressive and conducive to Fusarium wilt of watermelon. Phytopathology 83:1097-1105.

29. Lupwayi, N. Z., Rice, W. A., and Clayton, G. W. 1998. Soil microbial diversity and community structure under wheat as influenced by tillage and crop rotation. Soil Biol. Biochem. 30:1733-1741.

30. Marschner, P., Crowley, D., and Yang, C. H. 2004. Development of specific rhizosphere bacterial communities in relation to plant species, nutrition and soil type. Plant Soil 261:199-208.

31. Marschner, P., Yang, C.-H., Lieberei, R., and Crowley, D. E. 2001. Soil and plant specific effects on bacterial community composition in the rhizosphere. Soil Biol. Biochem. 33:1437-1445.

32. Miethling, R., Wieland, G., Backhaus, H., and Tebbe, C. C. 2000. Variation of microbial rhizosphere communities in response to crop species, soil origin, and inoculation with Sinorhizobium meliloti L33. Microbial Ecol. 41:43-56.

33. O'Donnell, A. G., Seasman, M., Macrae, A., Waite, I., and Davies, J. T. 2001. Plants and fertilisers as drivers of change in microbial community structure. Plant Soil 232:135-145.

34. Olsson, P. A. 1999. Signature fatty acids provide tools for determination of the distribution and interactions of mycorrhizal fungi in soil. FEMS Microbiol. Ecol. 29:303-310.

35. Peacock, A. D., Mullen, M. D., Ringelberg, D. B., Tyler, D. D., Hedrick, D. B., Gale, P. M., and White, D. C. 2001. Soil microbial community responses to dairy manure or ammonium nitrate applications. Soil Biol. Biochem. 33:1011-1019.

36. Peters, R. D., Sturz, A. V., Carter, M. R., and Sanderson, J. B. 2003. Developing disease-suppressive soils through crop rotations and tillage management practices. Soil Tillage Res. 72:181-192.

37. Sands, D. C., and Rovira, A. R. 1970. Isolation of fluorescent pseudomonads with a selective medium. Appl. Microbiol. 20:513-514.

38. Scholte, K. 1987. The effect of crop rotation and granular nematicides on the incidence of Rhizoctonia solani in potato. Potato Res. 30:187-199.

39. Siciliano, S. D., Theoret, C. M., de Freitas, J. R., Hucl, P. J., and Germida, J. J. 1998. Differences in the microbial communities associated with the roots of different cultivars of canola and wheat. Can. J. Microbiol. 44:844-851

40. Specht, L. P., and Leach, S. S. 1987. Effects of crop rotation on Rhizoctonia disease of white potato. Plant Dis. 71:433-437.

41. Spedding, T. A., Hamel, C., Mehuys, G. R., and Madramootoo, C. A. 2004. Soil microbial dynamics in maize-growing soil under different tillage and residue management systems. Soil Biol. Biochem. 36:499-512.

42. Talbot, M. M., and Larkin, R. P. 2002. Suppression of Rhizoctonia disease of potato by biological control and a ryegrass rotation. (Abstr.) Phytopathology 92(suppl.):S80.

43. Vepsäläinen, M., Erkoma, K., Kukkonen, S., Vestberg, M., Wallenius, K., and Niemi, R. M. 2004. The impact of crop plant cultivation and peat amendment on soil microbial activity and structure. Plant Soil 264:273286.

44. Wiggins, B. E., and Kinkel, L. L. 2005. Green manures and crop sequences influence potato diseases and pathogen inhibitory activity of indigenous streptomycetes. Phytopathology 95:178-185. 
45. Yao, H., He, Z., Wilson, M. J., and Campbell, C. D. 2000. Microbial biomass and community structure in a sequence of soils with increasing fertility and changing land use. Microbial Ecol. 40:223-237.

46. Zak, J. C., Willig, M. R., Moorhead, D. L., and Wildman, H. G. 1994. Functional diversity of microbial communities: A quantitative approach. Soil Biol. Biochem. 26:1101-1108.

47. Zelles, L., Bai, Q. Y., Beck, T., and Beese, F. 1992. Signature fatty acids in phospholipids and lipopolysaccharides as indicators of microbial biomass and community structure in agricultural soils. Soil Biol. Biochem. 24:317-323.

48. Zelles, L., Bai, Q. Y., Rackwitz, R., Chadwick, D., and Beese, F. 1995. Determination of phospholipid- and lipopolysaccharide-derived fatty acids as an estimate of microbial biomass and community structures in soils. Biol. Fertil. Soils 19:115-123. 